
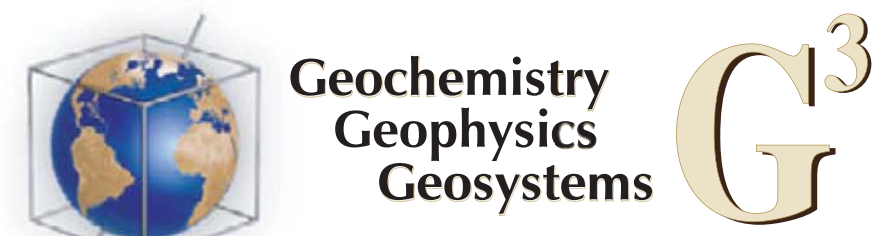

\title{
Mylonitic deformation at the Kane oceanic core complex : Implications for the rheological behavior of oceanic detachment faults
}

\author{
Lars N. Hansen \\ Department of Geological and Environmental Sciences, Stanford University, 450 Serra Mall, Building 320, \\ Stanford, California, 94305, USA (lars.norman.hansen@gmail.com)
}

\author{
Michael J. Cheadle, Barbara E. John, and Susan M. Swapp \\ Department of Geology and Geophysics, University of Wyoming, Wyoming, USA
}

\author{
Henry J. B. Dick, Brian E. Tucholke, and Maurice A. Tivey \\ Department of Geology and Geophysics, Woods Hole Oceanographic Institution, Woods Hole, Massachusetts, \\ USA
}

[1] The depth extent, strength, and composition of oceanic detachment faults remain poorly understood because the grade of deformation-related fabrics varies widely among sampled oceanic core complexes (OCCs). We address this issue by analyzing fault rocks collected from the Kane oceanic core complex at $23^{\circ} 30^{\prime} \mathrm{N}$ on the Mid-Atlantic Ridge. A portion of the sample suite was collected from a younger fault scarp that cuts the detachment surface and exposes the interior of the most prominent dome. The style of deformation was assessed as a function of proximity to the detachment surface, revealing a $\sim 450 \mathrm{~m}$ thick zone of high-temperature mylonitization overprinted by a $\sim 200 \mathrm{~m}$ thick zone of brittle deformation. Geothermometry of deformed gabbros demonstrates that crystal-plastic deformation occurred at temperatures $>700^{\circ} \mathrm{C}$. Analysis of the morphology of the complex in conjunction with recent thermochronology suggests that deformation initiated at depths of $\sim 7 \mathrm{~km}$. Thus we suggest the detachment system extended into or below the brittle-plastic transition (BPT). Microstructural evidence suggests that gabbros and peridotites with high-temperature fabrics were dominantly deforming by dislocationaccommodated processes and diffusion creep. Recrystallized grain size piezometry yields differential stresses consistent with those predicted by dry-plagioclase flow laws. The temperature and stress at the BPT determined from laboratory-derived constitutive models agree well with the lowest temperatures and highest stresses estimated from gabbro mylonites. We suggest that the variation in abundance of mylonites among oceanic core complexes can be explained by variation in the depth of the BPT, which depends to a first order on the thermal structure and water content of newly forming oceanic lithosphere.

Components : 13,868 words, 11 figures, 2 tables.

Keywords: oceanic core complex; oceanic detachment fault; mylonite; rheology of the lithosphere.

Index Terms : 3000 Marine Geology and Geophysics; 3035 Midocean ridge processes; 8100 Tectonophysics; 8159 Rheology: crust and lithosphere; 8162 Rheology: mantle; 8164 Stresses: crust and lithosphere; 8000 Structural Geology; 8031 Rheology: crust and lithosphere; 8033 Rheology: mantle; 3900 Mineral Physics; 3902 Creep and deformation.

Received 11 February 2013; Accepted 22 May 2013; Published 28 August 2013. 
Hansen L. N., M. J. Cheadle, B. E. John, S. M. Swapp, H. J. B. Dick, B. E. Tucholke, and M. A. Tivey (2013), Mylonitic deformation at the Kane oceanic core complex: Implications for the rheological behavior of oceanic detachment faults, Geochem. Geophys. Geosyst., 14, 3085-3108, doi:10.1002/ggge.20184.

\section{Introduction}

[2] Slow- and ultraslow-spreading ridges make up $60 \%$ of the Earth's mid-ocean ridge system, with oceanic core complexes recognized as a common feature along these ridges [e.g., Tucholke et al., 1996, 1998; Smith et al., 2006; Cannat et al., 2006; Escartín et al., 2008; John and Cheadle, 2010; Schoolmeesters, 2011]. Well-developed OCCs are characterized by a domed morphology with spreading-parallel corrugations, and areal extents from 150 to over $6000 \mathrm{~km}^{2}$. Samples collected from OCCs along the Mid-Atlantic Ridge [Mutter and Karson, 1992; Cann et al., 1997; MacLeod et al., 2002; Escartín et al., 2003; Schroeder and John, 2004; Dick et al., 2008; Blackman et al., 2011], the Southwest Indian Ridge [Cannat, 1991; Dick et al., 1991, 2000], and in the Parece Vela Basin [Ohara et al., 2003; Harigane et al., 2008] consist of serpentinized peridotite, gabbroic rocks, diabase, and basalt. Based on these morphologic and lithologic observations [Tucholke and Lin, 1994; Tucholke et al., 1996, 1998; Cann et al., 1997; Schroeder and John, 2004; Boschi et al., 2006; Karson et al., 2006; Smith et al., 2006; MacLeod et al., 2009] and associated numerical simulations [Lavier et al., 1999; Buck et al., 2005; Tucholke et al., 2008; Olive et al., 2010], OCCs are hypothesized to be bounded by normal faults with apparent offsets of $\sim 15-125 \mathrm{~km}$ that undergo flexural rotation (i.e., "roll over") while tectonically denuding the lower crust and upper mantle.

[3] The ubiquity of OCCs at slow- and ultraslowspreading mid-ocean ridges implies that the rheological behavior of oceanic detachment faults is a key process in the generation of new oceanic lithosphere. Yet the depth extent, strength, and composition of fault-rock assemblages of oceanic detachment faults remain poorly understood. In general, samples from oceanic detachment faults exhibit evidence of pervasive interaction between fault rocks and seawater which produces weak, hydrous alteration phases [MacLeod et al., 2002; Escartín et al., 2003; Schroeder and John, 2004; Boschi et al., 2006; Paulick et al., 2006; Harigane et al., 2008; McCaig et al., 2010; Picazo et al., 2012]. However, evidence for high-temperature, viscous deformation related to detachment faulting varies from relatively little [MacLeod et al., 2002; Escartín et al., 2003; Kelemen et al., 2004; Hirose and Hayman, 2008], to moderate [Schroeder and John, 2004; Karson et al., 2006; Harigane et al., 2008; Picazo et al., 2012], to pervasive [Dick et al., 2000; Mehl and Hirth, 2008; Miranda and John, 2010]. Additionally, some microstructural observations have led to the suggestion that a melt phase plays an important role in the deepest portions of the system [Agar and Lloyd, 1997; Dick et al., 1991, 2000]. Because long-lived detachment faults likely need a rheological boundary for localization [Searle and Escartin, 2004], the above observations have led to four primary models for the initial localization/rooting of the fault system at depth: (1) an alteration front [Escartin et al., 2003], (2) the brittle-plastic transition (BPT) [Tucholke et al., 1998, 2001, 2008; Schroeder and John, 2004], (3) the boundary between gabbro intrusions and weakened hydrated peridotite [Ildefonse et al., 2007], or (4) a melt-rich zone [Dick et al., 1991, 2000].

[4] In an attempt to better understand the rheological behavior of oceanic detachment faults, we examine the characteristics of deformation associated with the central section of the Kane OCC at $23^{\circ} 30^{\prime} \mathrm{N}$ on the Mid-Atlantic Ridge (Figure 1). By looking at the spatial distribution of fault rocks, combined with petrographic, crystallographic, and thermometric analysis of fault rocks that have undergone high-temperature deformation, we demonstrate that the Kane oceanic detachment fault was initiated at high temperature and extended below the BPT. Finally, we attempt to reconcile the varying styles of deformation recorded by fault rocks collected from other OCCs by combining microstructural observations with laboratory-derived constitutive models for rock deformation to produce an overarching picture of oceanic detachment-fault rheology.

\section{Geological Overview of the Kane OCC}

[5] The Kane OCC is centered near $23^{\circ} 30^{\prime} \mathrm{N}$, $45^{\circ} 20^{\prime} \mathrm{W}$ on the western flank of the Mid-Atlantic 

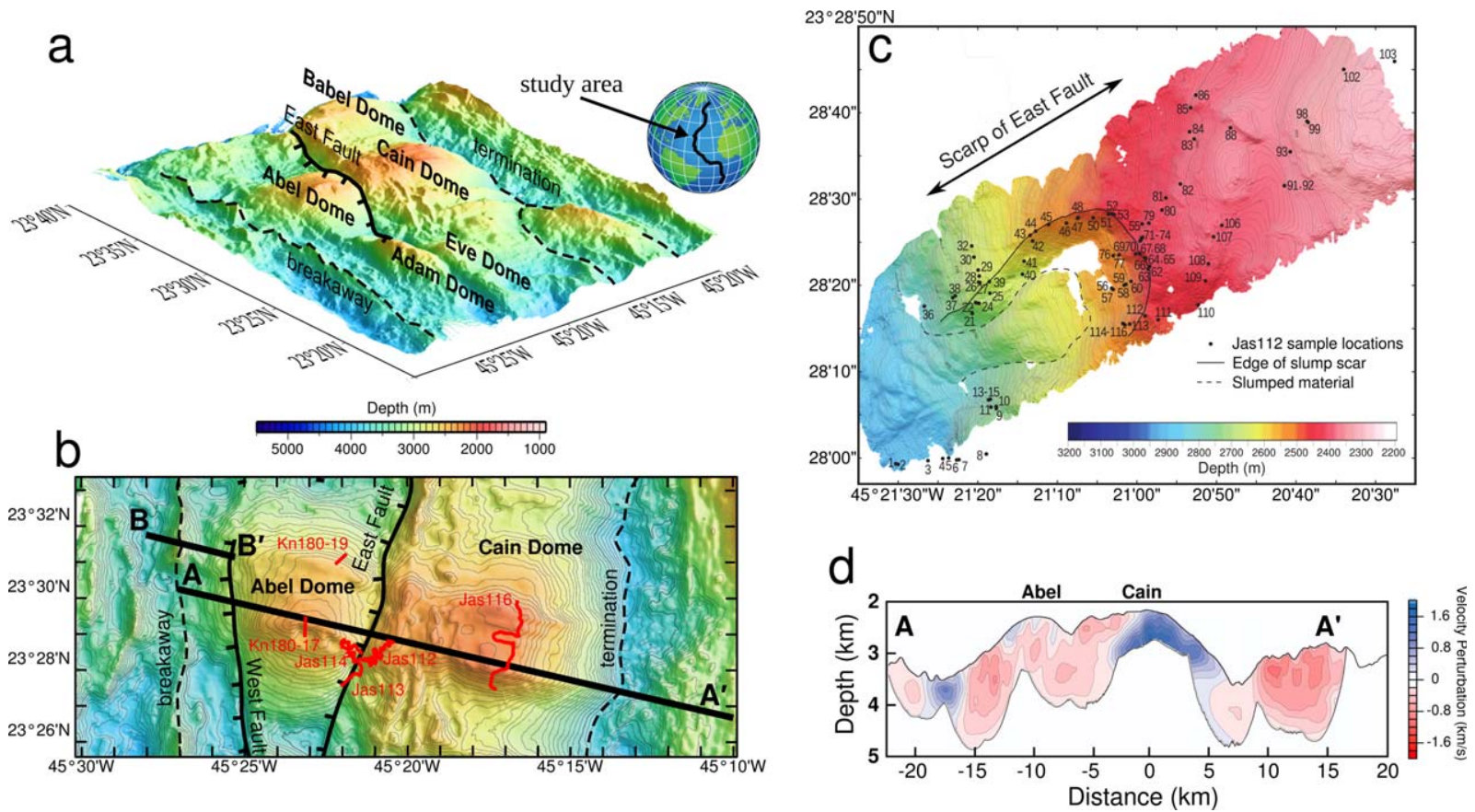

Figure 1. General structure and sampling locations at the Kane OCC. (a) Oblique view of Kane OCC bathymetry with locations of East Fault and detachment fault breakaway and termination. (b) Map view of Abel and Cain Dome bathymetry with major faults indicated [after Tivey et al., 2004; Dick et al., 2008]. Red lines denote locations of dredges and dives from which samples used in this study were collected. Thick lines indicate locations of cross sections $\mathrm{A}-\mathrm{A}^{\prime}$ and $\mathrm{B}-\mathrm{B}^{\prime}$, which appear in Figure 1d and Figure 8, respectively. The same depth scale is used for Figures 1a and 1b. (c) Detailed bathymetry of East Fault scarp surveyed by the autonomous vehicle ABE in vicinity of Jas 112 drive track. Locations of samples used to construct profiles in Figure 2 are indicated with sample numbers. (d) Velocity perturbation model from Xu et al. [2009]. Velocity perturbations are differences from an initial 1-D velocity model. The blue region on the east flank of Cain Dome is interpreted as seismically fast gabbro, while the pink regions of Cain and Abel Domes are interpreted as seismically slow, serpentinized peridotite.

Ridge just south of Kane Fracture Zone (Figure 1) and extends from $\sim 3.5 \mathrm{Ma}$ crust at the breakaway to $\sim 2.2 \mathrm{Ma}$ crust at the termination [Tivey et al., 2004; Cheadle et al., 2008; Dick et al., 2008; Schoolmeesters, 2011]. The OCC is $\sim 580 \mathrm{~km}^{2}$ in areal extent and exhibits several structural domes that are corrugated parallel to the fracture zone: the northern Babel Dome $(\sim 12 \mathrm{~km}$ long parallel to the spreading direction), the central Cain and Abel Domes ( $\sim 25 \mathrm{~km}$ long), and the southern Adam and Eve Domes ( $\sim 6 \mathrm{~km}$ long and $\sim 4 \mathrm{~km}$ long, respectively) [Tivey et al., 2004; Dick et al., 2008]. The Kane OCC is similar in size and morphology to other recognized detachmentbounded OCCs [e.g., Blackman et al., 1998; Tucholke et al., 1998]. Additional similarities include residual mantle Bouger gravity that is elevated $(\sim 10-15 \mathrm{mGal})$ over much of the core complex [Maia and Gente, 1998; Dick et al., 2008], suggesting that the massif is cored by high-density rocks.
[6] The complex is dissected by several normal faults that trend parallel to the ridge axis (Figure 1). The $35 \mathrm{~km}$ long East Fault, a down-to-the west normal fault, truncates the western edge of Babel Dome and separates Cain and Abel Domes. At Cain Dome, the fault trace is defined by a $\sim 500 \mathrm{~m}$ high scarp, which exposes the interior structure of the dome and provides an excellent opportunity to collect samples from below the main detachment surface.

[7] Based on the same sample suite used in this study, Dick et al. [2008] mapped the architecture of the Kane OCC from the Kane Transform to the southern edge of Eve Dome. They interpreted Babel Dome in the north and Adam and Eve Domes in the south to represent two exposed fossil magmatic centers. In contrast to those domes, Dick et al. [2008] suggested the central Cain and Abel Domes represent an area of very limited magmatism due to the relative lack of recovered dunite 
and primitive gabbros. Xu et al. [2009] further elucidated the internal structure of the Kane OCC using seismic tomographic models along several cross sections through the complex. Their velocity model of the central section (Figure $1 \mathrm{~b}$ ) is consistent with the interpretation that Cain and Abel Domes are largely composed of low-velocity, serpentinized ultramafic rocks, although the east flank of Cain Dome appears to be cored by a higher velocity body, which they interpret as a series of gabbroic intrusions.

\section{Methods}

\subsection{Sample Collection and Profile Construction}

[8] The Kane OCC was investigated by extensive magnetic, bathymetric, and sampling surveys during R/V Knorr Cruise 180, Leg 2 [Tivey et al., 2004; Dick et al., 2008]. Samples were collected in 28 dredges and during seven dives with the remotely operated vehicle Jason II, and $\sim 2600 \mathrm{~kg}$ of rock consisting dominantly of peridotite, dunite, gabbro, diabase, and basalt were recovered. A number of samples determined to be in situ were geographically oriented using Jason II compass orientation and video footage. Hand samples were characterized based on their primary mineralogy, alteration mineralogy, and deformation fabrics immediately after sampling. For this study, we reanalyzed the deformation fabric intensity present in each sample using available thin sections to supplement observations from hand samples. We used a scale of $0-5$ to describe both brittle and crystalplastic deformation fabric intensity [Dick et al., 1999; Schroeder and John, 2004, Table 2; Dick et al., 2008]. We assume crystal-plastic deformation occurs at depths below the BPT, and we therefore include semibrittle deformation with brittle deformation. For brittle fabrics, an intensity of 0 corresponds to undeformed, 3 corresponds to significant brecciation with clast rotation, and 5 corresponds to an ultracataclasite. For crystal-plastic fabrics, an intensity of 0 corresponds to an undeformed rock, 3 corresponds to a protomylonite, and 5 corresponds to an ultramylonite.

[9] To examine the spatial distribution of deformation below the main detachment surface, we constructed profiles of deformation fabrics as a function of depth using rocks collected by Jason II on dive Jas 112 from the East Fault scarp on the west flank of Cain Dome (Figure 1). Samples col- lected from material clearly contained within a large slump mass (Figure 1c) were not included in the analysis. Because (1) the East Fault exposes the interior of Cain Dome, and (2) the surface of Cain Dome represents the main detachment surface, the depth of any rock below the detachment surface can be determined from the bathymetric depth after correcting for the dip of the fault scarp relative to the projected dip of the detachment surface above the fault scarp. Here we extrapolate the dip of the detachment surface from the westernmost part of the Cain Dome and use a planar continuation dipping at $1.5^{\circ}$ to the west, the average dip of the surface of Cain Dome in the vicinity of cross section $\mathrm{A}-\mathrm{A}^{\prime}$ (Figure 2). A change in the projected dip of $\pm 5^{\circ}$ varies the total reconstructed section height by $\pm 95 \mathrm{~m}$. Any downslope movement of samples not collected in situ will exaggerate the thickness of the section, but given that many samples were collected from outcrop (see squares in Figure 2), we assume that this factor is not significant. Figure 2 plots both brittle and high-temperature deformation fabric intensities as a function of depth below the detachment surface.

\subsection{Microstructural Analysis}

[10] In order to examine a spectrum of deformation fabrics, we analyzed samples from dive Jas112 (Figure 2) as well as samples collected from dives Jas113 and Jas114 and two dredges, all in the area of Cain and Abel Domes. Deformationrelated microstructures were characterized through analysis of thin sections with both petrographic and electron microscopes. When possible, thin sections were cut perpendicular to foliation and parallel to lineation. We characterized fabrics based on grain shape, grain size distribution, subgrain development, undulose extinction, kink bands, and crystallographic-preferred orientations (CPOs). Any cross-cutting and overprinting relationships between fabric types were recorded.

[11] Crystallographic fabrics were measured using electron-backscatter diffraction (EBSD) on seven of the least-altered samples that are interpreted to span $\sim 1 \mathrm{~km}$ through the detachment fault system. Probe-polished thin sections were additionally polished with colloidal silica $(0.04 \mu \mathrm{m})$ for several hours and analyzed using a JEOL 5800LV scanning electron microscope with an attached HKL Technology electron backscatter detector. Data were acquired in a low-vacuum operating mode to enable examination of electrically insulating samples without application of a conductive coating. Data for relatively large areas were acquired by 

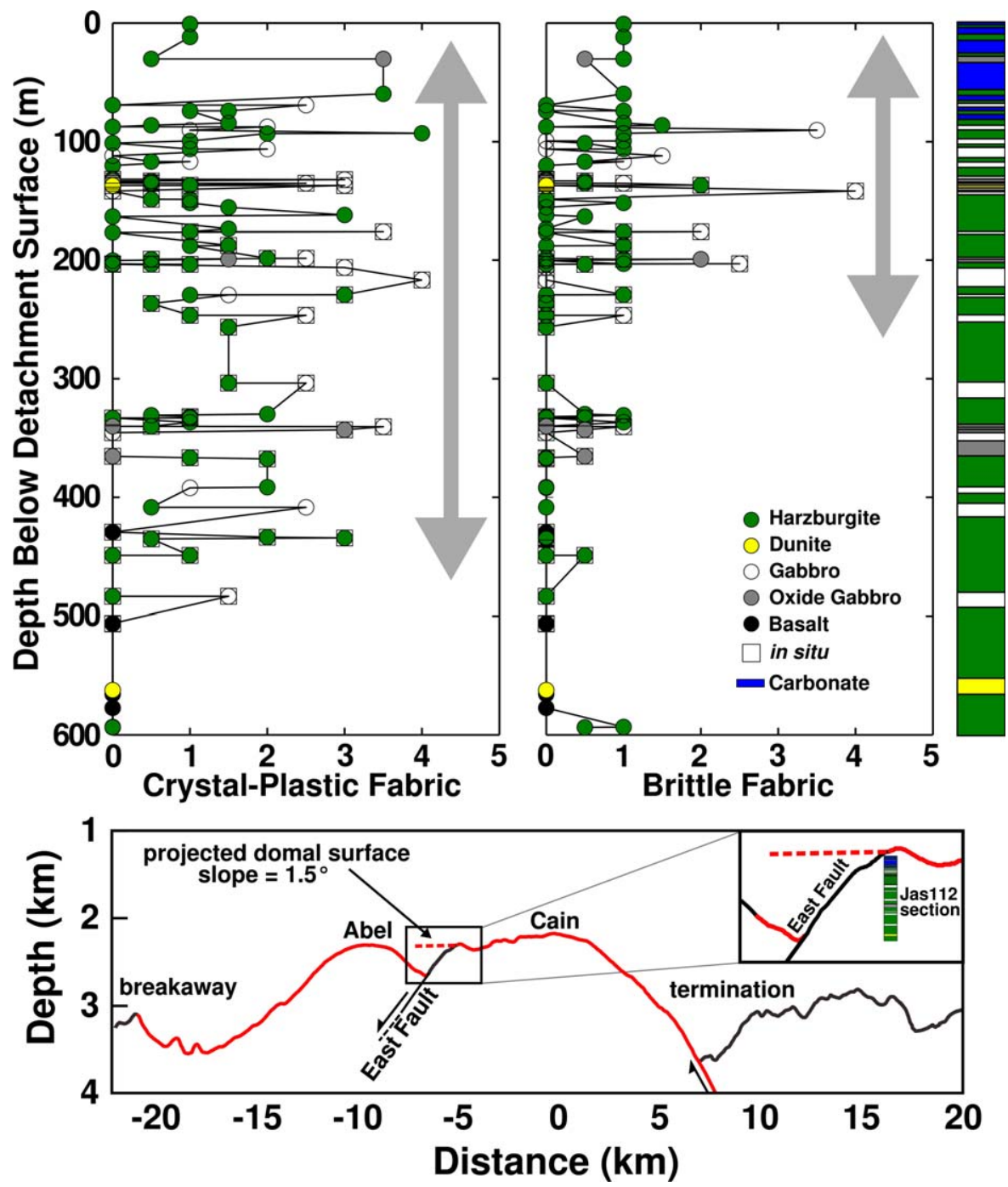

Figure 2. Reconstructed deformation-depth profiles from samples collected on dive Jas 112 (see Figure 1 for sample locations). The strength of the crystal-plastic and brittle fabric in each sample was categorized using a scale of $0-5$ (none to high strain). Colors indicate the rock type for each sample. Squares denote samples that appear to be in situ where they were collected. An $\sim 450 \mathrm{~m}$ envelope of crystal-plastic deformation is seen compared to an $\sim 200 \mathrm{~m}$ envelope of brittle deformation (denoted by gray arrows), suggesting localization of deformation toward the detachment surface as the footwall was tectonically denuded. Abundant carbonate talus in the upper $80 \mathrm{~m}$ of the section limited the recovery of igneous rocks. An interpreted lithologic column is shown on the right. The lower plot illustrates how the depth below sea level for each sample was converted to depth below the detachment surface. The red line denotes the main detachment surface. Data are available in supporting information, Table S1. ${ }^{1}$

stage mapping: the electron beam remained vertically incident on the sample surface while the sample was moved to acquire data for a grid of points, with step sizes ranging from 20 to $40 \mu \mathrm{m}$. Electron-backscatter patterns were indexed for olivine, plagioclase, orthopyroxene, clinopyroxene, ilmenite, magnetite, and hornblende using the HKL Channel 5 software package.

[12] Grain boundaries were defined to be a misorientation of $>15^{\circ}$ between neighboring pixels.
Subgrain boundaries were defined to be those with misorientations between 2 and $15^{\circ}$. When possible, data sets were filtered to one point per grain to prevent single grains from dominating pole figures. As listed in Table 1, the strengths of crystallographic fabrics were measured using the Mindex [Skemer et al., 2005], which is set on a scale of 0 (random fabric) to 1 (single crystal fabric).

\footnotetext{
${ }^{1}$ Additional supporting information may be found in the online version of this article.
} 
Table 1. Summary of Data Used for Rheological Analysis

\begin{tabular}{|c|c|c|c|c|c|c|c|c|}
\hline Sample & Rock Type & CP Fabric & $d^{\mathrm{a}}(\mu \mathrm{m})$ & $\sigma^{\mathrm{b}}(\mathrm{MPa})$ & Piezometer ${ }^{\mathrm{c}}$ & M-Index & $\mathrm{T}^{\mathrm{d}}\left({ }^{\circ} \mathrm{C}\right)$ & Location \\
\hline Jas112-32 & Amph gabbro & 3.5 & 90 & 49 & $\mathrm{~T}$ & 0.03 & 811 & East Fault scarp \\
\hline Jas113-20a & Amph gabbro & 2.5 & 52 & 71 & $\mathrm{~T}$ & 0.2 & 766 & East slope Abel Dome \\
\hline Jas113-20b & Amph gabbro & 4 & 29 & 106 & $\mathrm{~T}$ & 0.05 & 766 & East slope Abel Dome \\
\hline Jas114-2 & Amph gabbro & 3.5 & 54 & 70 & $\mathrm{~T}$ & 0.12 & & East slope Abel Dome, in situ \\
\hline Kn180-19-4 & Fe-Ti oxide gabbro & 5 & 32 & 99 & $\mathrm{~T}$ & 0.02 & & North slope Abel Dome \\
\hline Kn180-19-12a & Plag layer & 3.5 & 172 & 31 & $\mathrm{~T}$ & 0.07 & 848 & North slope Abel Dome \\
\hline Kn180-19-12b & Gabbronorite & 3.5 & 95 & 26 & $\mathrm{MH}$ & 0.07 & 848 & North slope Abel Dome \\
\hline Jas112-93b & Harzburgite & 3.5 & 99 & 43 & VW & 0.15 & & $\begin{array}{l}\text { Detachment surface upslope of } \\
\text { East Fault scarp }\end{array}$ \\
\hline Kn180-17-14a & Harzburgite & 2.5 & 78 & 51 & VW & 0.21 & & South slope Abel Dome \\
\hline Kn180-17-14b & Harzburgite & 2.5 & 95 & 44 & VW & 0.14 & & South slope Abel Dome \\
\hline
\end{tabular}

${ }^{\mathrm{a}}$ Mean recrystallized grain size.

${ }^{\mathrm{b}}$ Estimated differential stress.

${ }^{\mathrm{c} G r a i n ~ s i z e ~ p i e z o m e t e r s ~ u s e d ~ a r e ~ f r o m ~(T) ~ T w i s s ~[1977], ~(M H) ~ M e h l ~ a n d ~ H i r t h ~[2008], ~ a n d ~(V W) ~ v a n ~ d e r ~ W a l ~ e t ~ a l . ~[1993] . ~}$

${ }^{\mathrm{d}}$ Temperatures are averages of those calculated for multiple mineral pairs as reported in Table $\mathrm{S} 1$.

\subsection{Grain Size Piezometry}

[13] Measurements of recrystallized grain size were used to estimate differential stress during deformation. Average recrystallized grain sizes were measured using the linear intercept method on photomicrographs of thin sections. A correction factor of 1.5 was applied to average intercept lengths to approximate the 3-D average grain size [Underwood, 1970, pp. 80-93]. The anorthosite piezometer from Twiss [1977] was used to calculate paleostresses in plagioclase-rich regions. The Twiss [1977] piezometer was also used by Mehl and Hirth [2008] to estimate a polyphase piezometric relationship in mixtures of plagioclase and pyroxene. We use this estimated piezometric relationship to calculate paleostress in the polyphase layers of a layered gabbronorite (Kn180-19-12). The olivine piezometer from [van der Wal et al., 1993] was used to calculate paleostresses in samples of peridotite. Calculated stresses are listed in Table 1.

\subsection{Thermometry}

[14] Deformation temperatures of amphibolebearing gabbros were constrained by the plagioclase-amphibole thermometer of Holland and Blundy [1994]. Equilibrium B of Holland and Blundy [1994] is based on the exchange of Al and $\mathrm{Na}$ between amphibole and plagioclase and does not require quartz saturation. The application of this thermometer to oceanic gabbros is detailed in Manning et al. [1996]. Chemical compositions of plagioclase and amphibole were determined using a JEOL JXA-8900 five-spectrometer electron microprobe. Adjacent plagioclase and amphibole grain pairs were sampled from 15 to $40 \mu \mathrm{m}$ from shared grain boundaries. Measured total Fe was redistributed among the $\mathrm{Fe}^{2+}$ and $\mathrm{Fe}^{3+}$ oxidation states following the method of Dale et al. [2000]. A similar method was used to analyze orthopyroxene and clinopyroxene pairs. Temperatures were calculated using the Ca-QUILF thermometer [Lindsley and Frost, 1992; Anderson et al., 1993]. Potential sources of error include uncertainty in the thermometer, analytical uncertainty, lowtemperature diffusion across grain boundaries, and nonequilibrium between measured phases.

[15] Deformation temperatures were not determined for peridotites. Although a variety of geothermometers have been calibrated for use in peridotites [Fabries, 1979; Brey and Köhler, 1990; Sack and Ghiorso, 1991; Witt-Eickschen and Seck, 1991], calculated temperatures can only be assumed to represent deformation conditions if neoblast pairs are analyzed. Neoblasts of a necessary second phase (orthopyroxene, clinopyroxene, or spinel) are not present in our unaltered samples, which reduces the reliability of any calculated temperatures.

\section{Results}

[16] A large proportion of the rocks collected from the Kane OCC during R/V Knorr Cruise 180, Leg $2(\sim 25 \%)$ exhibit significant mylonitization and/or brittle deformation, and many samples preserve a retrograde deformation and alteration history. In general, a down-temperature sequence of overprinting fabrics is observed and characterized by initial granulite- or amphibolite-grade mylonitic fabrics that are subsequently overprinted by greenschist retrogression; the development of a distinct schistosity often defined by talc, tremolite, or chlorite; and finally brecciation or cataclastic 
deformation. We first examine the spatial distribution of deformed rocks and then focus on the hightemperature microstructures related to the deepest portions of the detachment system.

\subsection{Spatial Variations in Deformation}

[17] As demonstrated by Dick et al. [2008], the surface of each prominent dome (Cain, Abel, Babel, Eve, and Adam) hosts a high proportion of deformed rocks, consistent with the hypothesis that these surfaces are exposed detachment faults. Of the samples collected, $26 \%$ have a fabric intensity (brittle and/or crystal plastic) greater than 3 . This density of fault rocks is in contrast to rocks collected from the scarps of East and West faults, where only $7 \%$ have a fabric intensity greater than 3. As illustrated in Figure 3, measured foliations in oriented samples are subparallel to the average orientation of the main detachment surface (diping $10-30^{\circ}$ to the southeast).

[18] The depth profile of deformation fabric intensity (Figure 2 and Table S1; supporting information) allows investigation of variations in distribution and magnitude of strain below the detachment surface to characterize the detachment zone. The samples used to construct this profile are dominated by peridotite ( $88 \mathrm{wt} \%)$ and gabbro

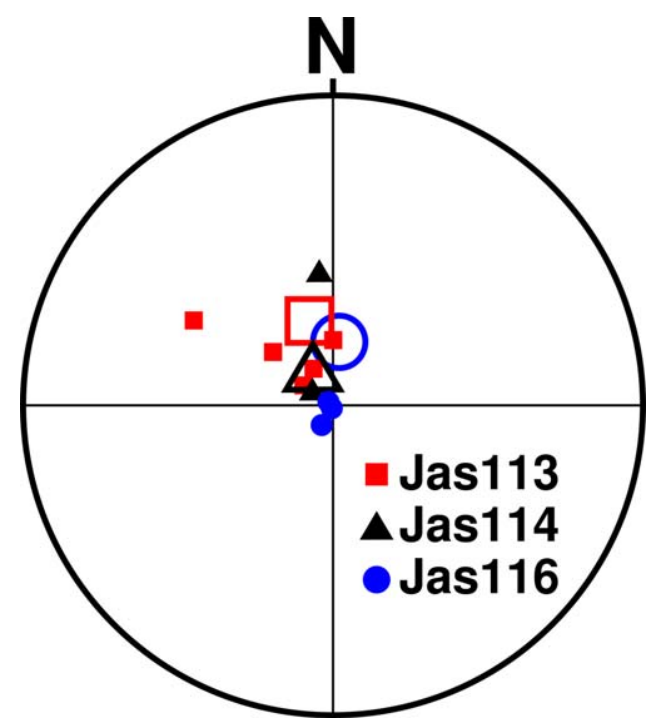

Figure 3. Poles to mylonitic foliation of in situ samples plotted on a lower-hemisphere equal-angle stereonet. Large, open, symbols represent poles to the detachment surface nearest to sampled outcrops. Small, filled, symbols represent poles to foliation measured in hand samples. Orientations of foliations in hand samples are estimated to be accurate to within $\pm 20^{\circ}$. Data are available in Table S2 (supporting information).
(10 wt\%) with lesser amounts of dunite and diabase [Dick et al., 2008]. Several samples of harzburgite are intruded by gabbroic veins, some of which are obviously incorporated into the hightemperature deformation zones (see section 4.2.1.2). There is abundant carbonate talus on the uppermost part of the scarp, which limited recovery of igneous rocks near the main detachment surface.

[19] Figure 2 demonstrates that, in general, deformation fabrics increase in intensity at higher structural levels adjacent to the detachment fault, with broad zones of both high-temperature and brittle deformation near the top of the section. Protomylonitic to mylonitic deformation is contained in a $\sim 450 \mathrm{~m}$ thick envelope. Intense brittle deformation $(>2)$ is present to depths of $\sim 200 \mathrm{~m}$. In the upper $\sim 450 \mathrm{~m}, 23 \%$ of sampled rocks show significant high-temperature deformation, and in the upper $\sim 200 \mathrm{~m}, 15 \%$ of sampled rocks show significant brittle deformation. These percentages are significantly higher than percentages for all samples collected on dive Jas112 (18\% high temperature, $5 \%$ brittle) and are only slightly lower than the percentages of deformed rocks recovered from the surface of Cain Dome (26\% high temperature, $20 \%$ brittle) [Dick et al., 2008]. We note that the presence of undeformed rocks intermingled with highly deformed rocks is consistent with observations of hand specimens in which centimeter-wide mylonitic shear zones can be observed. Based on these observations, we suggest that (1) the Kane detachment fault system is characterized by a broad zone of high-temperature deformation that localized into a narrower zone of brittle deformation, and (2) both high-temperature and brittle systems are composed of many discrete shear zones on the order of centimeters to meters thick, surrounding less deformed rocks interspersed between these shear zones.

\subsection{Characterization of Deformation Conditions}

\subsubsection{High-Temperature Mylonitic Microstructures}

[20] Gabbronorites, amphibole-bearing gabbros, and Fe-Ti oxide gabbros sampled from the Cain and Abel Domes exhibit mylonitic microstructures characteristic of high-temperature, crystal-plastic deformation (Figure 4). Plagioclase in gabbroic mylonites exhibits extensive core-and-mantle structure, ribbon-shaped porphyroclasts, and subgrain development. Neoblasts and subgrains are similarly sized $(30-200 \mu \mathrm{m})$ and significantly 

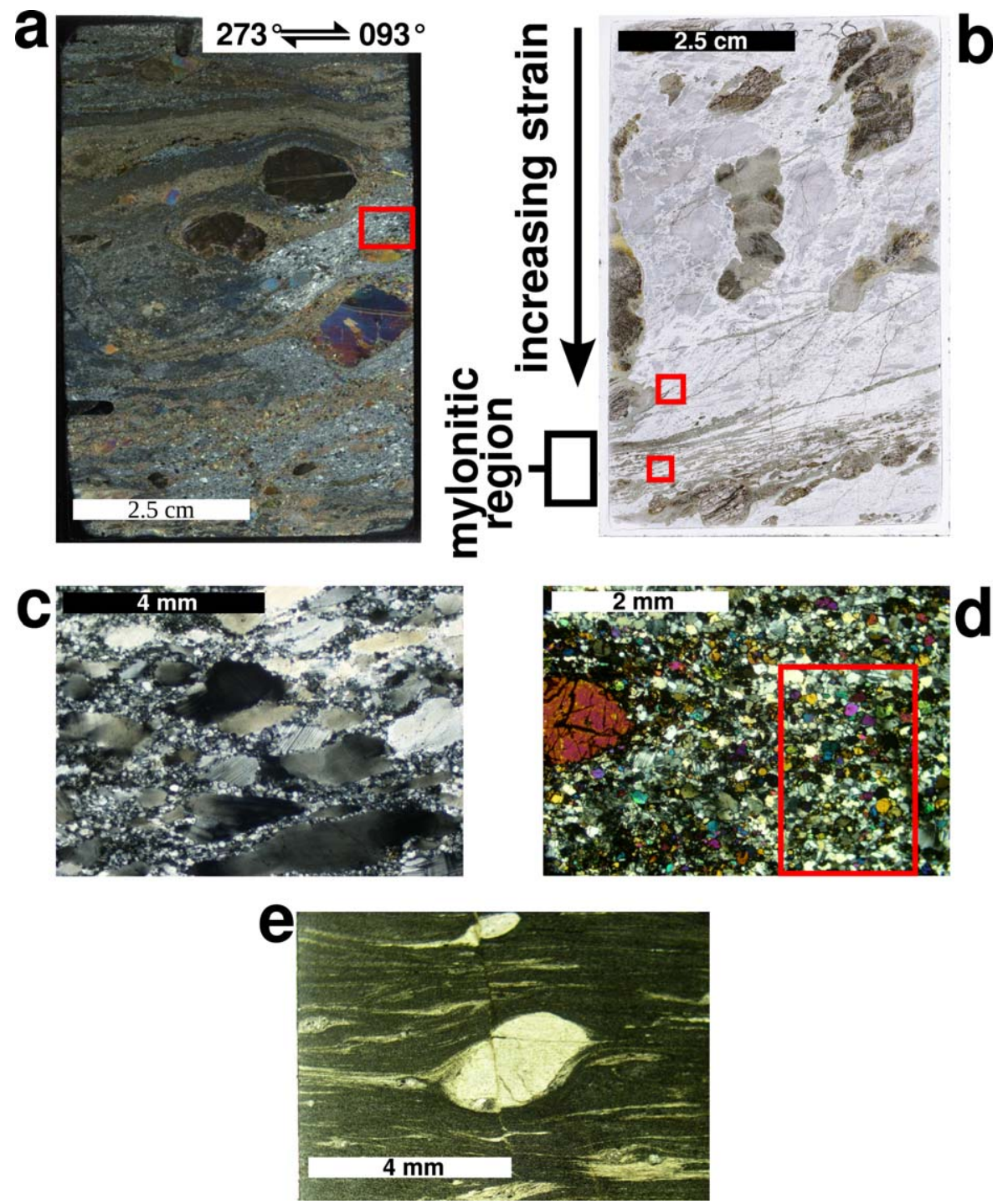

Figure 4. Characteristic microstructures of gabbroic mylonites (crossed nicols: Figures 4a, 4c, and 4d; plane-polarized light: Figures $4 \mathrm{~b}$ and $4 \mathrm{e}$ ). The shear sense is oriented top to the right for all images. The red boxes indicate regions analyzed with EBSD. (a) Plagioclase, pyroxene, and hornblende in an oriented gabbro mylonite (Jas114-2). Tails of recrystallized amphibole have retrogressed to hornblende and define the crystalplastic foliation. Plagioclase forms the matrix and is substantially recrystallized. The foliation dips $\sim 45^{\circ}$ to the south. (b) Gabbro mylonite exhibiting large gradients in deformation (Jas113-20). The highest strain region is composed of fine layers of amphibole and plagioclase and is significantly finer grained than the lowstrain region. (c) Dynamically recrystallized plagioclase with core-and-mantle structure (Jas113-20). Plagioclase porphyroclasts have significant subgrain formation and twinning. Photo is taken from just outside the high-strain region in Figure 4b. (d) Fine-grained gabbronorite mylonite (Kn180-19-12). Recrystallized grains of pyroxene and plagioclase are well mixed. (e) The most intensely deformed rock collected from the Kane OCC, an oxide gabbro ultramylonite (Kn180-19-4). Large plagioclase porphyroclasts have recrystallized tails that mark the foliation. The matrix is dominated by very fine-grained plagioclase, ilmenite, and amphibole.

smaller than plagioclase porphyroclasts $(500-1000$ $\mu \mathrm{m})$. Neoblasts are equigranular and lack significant internal deformation, which suggests that subgrain development and neoblast formation has served as a recovery mechanism after extensive dislocation nucleation during intragranular dislo- cation creep. This texture has often been attributed to subgrain rotation as a mechanism for dynamic recrystallization [e.g., Drury and Urai, 1990; Hirth and Tullis, 1992]. Amphibole-bearing gabbros commonly exhibit alternating bands of brown-green amphibole and plagioclase defining a 
millimeter- to centimeter-scale foliation. Amphibole forms rims on pyroxene grains and extends from the pyroxene hosts in fine-grained, monophase tails. Several gabbro mylonites contain elongate stringers of Fe-Ti-rich melt that follow the mylonitic foliation while some relatively undeformed pockets of Fe-Ti-rich melt surround brittle fractured plagioclase and pyroxene, which suggests that a highly evolved melt phase was intruding the fault rocks throughout the deformation history (i.e., premylonitization, synmylonitization, and postmylonitization). One ultramylonite was collected from the surface of Abel Dome, recording the highest strain of all samples (Figure 4e). Pyroxene, zircon, and a few plagioclase porphyroclasts sit in a very fine-grained, well-mixed matrix of plagioclase, ilmenite, and amphibole. Plagioclase porphyroclasts have intense undulose extinction and are mantled by fine-grained neoblasts.

[21] Several deformed peridotites without a heavy brittle overprint were collected from both the surface of Cain and Abel Domes and the East Fault scarp. These are, in general, extensively serpentinized and exhibit low-temperature, static retrogression (i.e., alteration of pyroxene to finegrained tremolitic amphibole). The latest stages of alteration largely prevent the identification of many of the high-temperature microstructures. However, even in the most severely altered samples in which the original mineralogy is no longer present, relict protomylonitic and mylonitic fabrics can be recognized as asymmetric porphyroclasts with fine-grained tails hosted by a fine-grained matrix (Figures 5a and 5b). Several samples collected from the surfaces of Cain and Abel Domes exhibit a mylonitic fabric despite late brittle deformation. The highest-temperature fabrics are characterized by large pyroxene porphyroclasts that are often kinked and bent suggesting at least limited plasticity, and their asymmetry provides a sense of shear. Tails of recrystallized pyroxene that have since severely retrogressed, extend from the large porphyroclasts and define a foliation. Foliations and senses of shear determined from oriented samples indicate shear planes subparallel to the main detachment and slip directions consistent with that of the detachment system. Fine-grained matrices consist of tremolite, magnetite, serpentine, and talc, and the olivine can sometimes be identified as the fine-grained, prealteration phase.

[22] Although rare, several relatively unaltered peridotite mylonites were collected. Olivine in these samples (Figure 5c) has a well-developed coreand-mantle structure with ribbon-shaped porphyroclasts and subgrain development. Olivine neoblasts and subgrains are similarly sized $(\sim 100 \mu \mathrm{m})$ and significantly smaller than olivine porphyroclasts $(\sim 1000 \mu \mathrm{m})$. Some tails of unaltered, recrystallized pyroxene extend from pyroxene porphyroclasts. These observations indicate the operation of deformation and recrystallization mechanisms in the olivine-rich rocks similar to those interpreted for the plagioclase-rich rocks.

[23] Several deformed peridotites host gabbroic veins that appear to have been emplaced during deformation. The detail of one of these samples is depicted in Figure 5d. Aggregates of fine-grained olivine are surrounded by a matrix of chlorite and epidote. The matrix also contains relict amphibole and zircon, confirming the gabbroic origin. Optical inspection of olivine with a retardation plate shows a significant preferred orientation. Further details of the crystallographic fabric are discussed below. The fine-grained nature and preferred orientation of the olivine indicates deformation prior to intrusion, while schistose fabrics developed in the gabbroic matrix suggest further deformation subsequent to intrusion.

\subsubsection{CPOs: Plagioclase}

[24] CPOs of plagioclase are plotted in Figure 6. We examined plagioclase CPOs in three amphibole-bearing gabbro mylonites, one $\mathrm{Fe}-\mathrm{Ti}$ oxide gabbro ultramylonite, and one layered gabbronorite mylonite. In two cases, we mapped two areas (denoted by "a" and "b") of differing plagioclase grain size and fabric within the same thin section. Plagioclase CPO strengths were quantified using the M-index [Skemer et al., 2005] and range from 0.03 to 0.20 . Although there is significant variation in the magnitude and orientation of the CPO, samples with the strongest CPOs (Jas11320a, Jas114-2, Kn180-19-12a and b) tend to have clusters of [100] axes aligned with the shear direction (Figure 6). The [010] axes tend to be grouped into weak point maxima oriented perpendicular to the shear plane. These data are consistent with deformation being accommodated primarily by activation of the (010)[100] and (010)[001] slip systems. The (010)[100] and (010)[001] slip systems have been documented as primary slip systems during high-temperature $\left(750-900^{\circ} \mathrm{C}\right)$ deformation of plagioclase by transmission electron microscopy [e.g., Olsen and Kohlstedt, 1984], by examination of CPOs in experimentally deformed rocks [e.g., Ji and Mainprice,1990; 

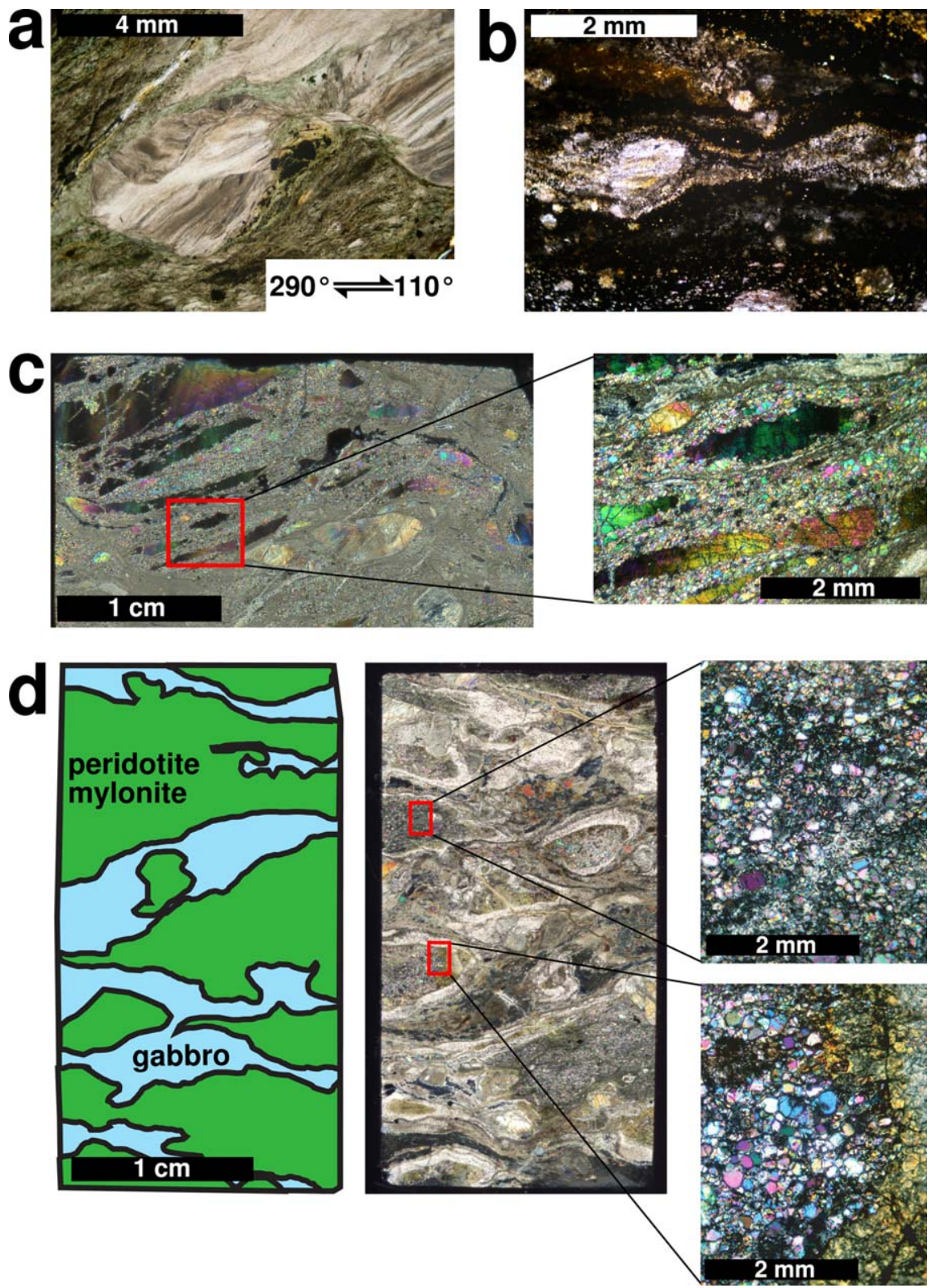

Figure 5. Characteristic microstructures of peridotite protomylonites and mylonites (crossed nicols). The shear sense is oriented top to the right for all images. The red boxes indicate regions analyzed with EBSD. (a) Oriented image of a peridotite mylonite that has been significantly altered and overprinted by brittle deformation, and is now seen as a fractured talc clast in a fine-grained tremolite-serpentine matrix (Jas116-16). The shear sense matches that of the overall detachment. (b) Statically altered peridotite mylonite (Jas113-36). Large altered pyroxene grains sit in a matrix of olivine retrogressing to magnetite, serpentine, and amphibole. (c) Relatively unaltered peridotite mylonite (Kn180-17-14). Pyroxenes and olivine porphyroclasts are asymmetric in a manner consistent with the top to the right shear sense. Olivine porphyroclasts are dynamically recrystallized into a fine-grained olivine matrix. Undulose extinction and subgrain development is ubiquitous in the large grains. (d) Peridotite mylonite intruded by a gabbroic melt (Jas112-93). The full thin section image is accompanied by a schematic interpretation denoting the peridotite host and the intruding gabbro. Peridotite aggregates are chiefly composed of very fine-grained olivine, indicating significant grain size reduction and mylonitization.

Stünitz et al., 2003], and by examination of CPOs in naturally deformed rocks [e.g., Xie et al., 2003; Mehl and Hirth, 2008]. Several samples exhibit randomly distributed plagioclase orientations (e.g., Jas112-32, and Kn180-19-4) with low M indices $(M<0.03)$. The weakest fabrics tend to 


\section{$\left[\begin{array}{lll}1 & 0 & 0\end{array}\right] \quad\left[\begin{array}{lll}0 & 1 & 0\end{array}\right] \quad\left[\begin{array}{lll}0 & 0 & 1\end{array}\right]$}

Jas112-32
amph gabbro
559 grains
$\max =3.1$
$M=0.03$

Jas113-20a amph gabbro 606 grains $\max =6.8$ $\mathrm{M}=\mathbf{0 . 2 0}$

Jas113-20b amph gabbro 700 grains $\max =2.4$ $M=0.05$

Jas114-2 amph gabbro 491 grains $\max =3.8$ $\mathrm{M}=\mathbf{0 . 1 2}$ $273^{\circ} \rightleftharpoons 093^{\circ}$

Kn180-19-4 oxide gabbro 1345 grains $\max =\mathbf{2 . 0}$ $\mathbf{M}=0.02$
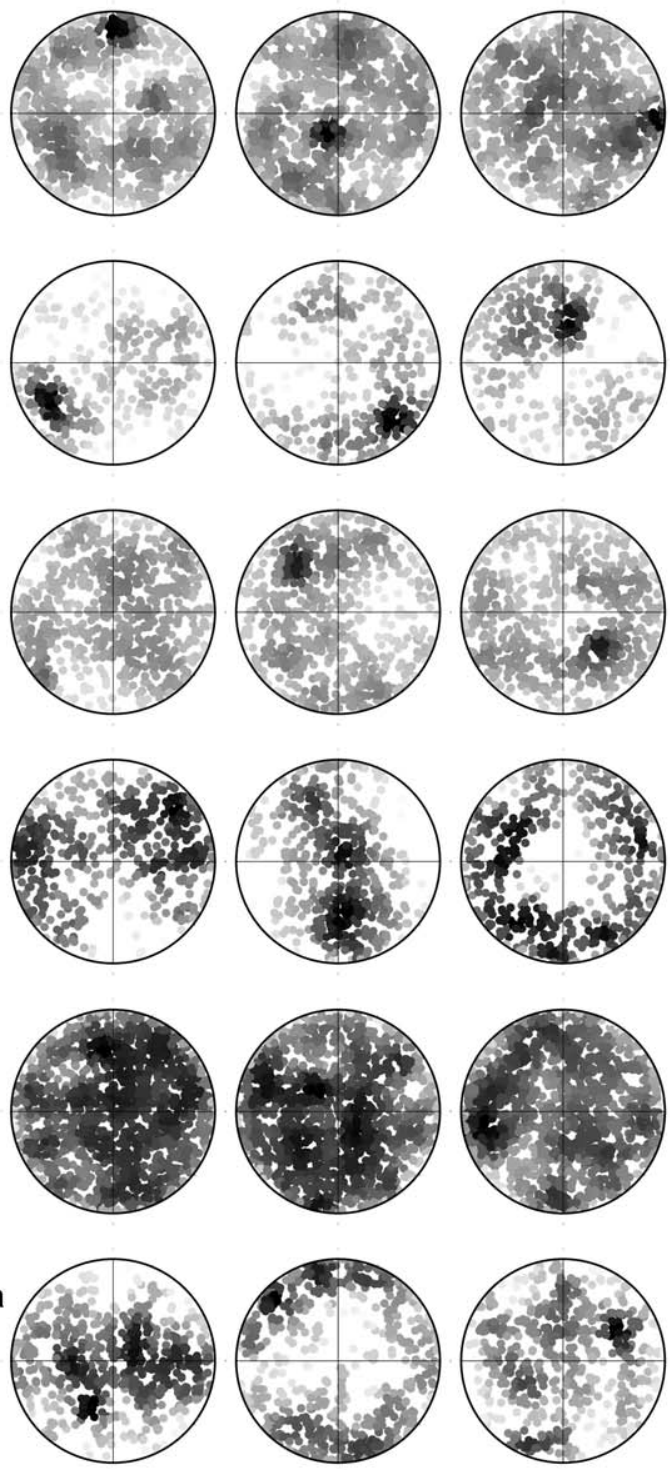

$M=0.07$

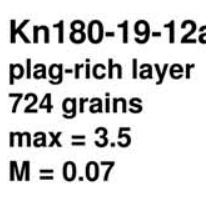

Kn180-19-12b gabbronorite 521 grains $\max =2.5$

$M=0.07$
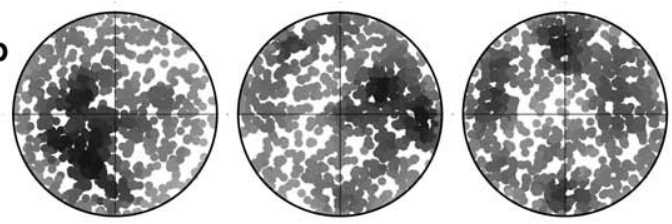

PF key
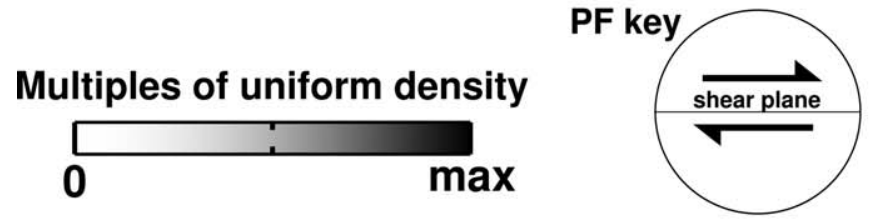

IPF
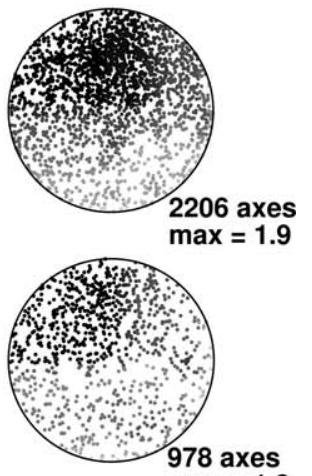

$\max =1.8$
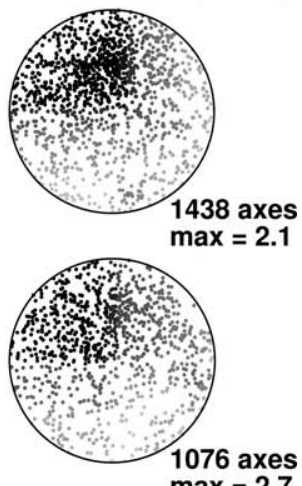

$\max =2.7$
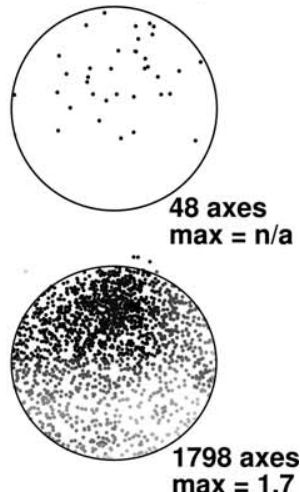

$\max =1.7$

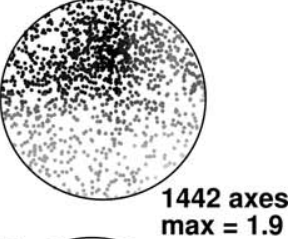

IPF key

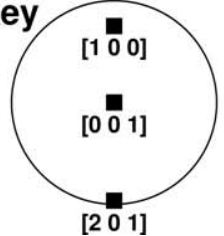

Figure 6. Pole figures (PF) and inverse pole figures (IPF) for plagioclase in the gabbros. For pole figures, all EBSD data were filtered to one point per grain, and the number of grains is given along with the calculated M-index. All pole figures are lower-hemisphere, equal-area plots. For inverse pole figures, correlated misorientations between $2^{\circ}$ and $15^{\circ}$ are plotted in the crystallographic reference frame. Details of the reference frames are given in the legend. 
be associated with the smallest grain sizes (Table 1).

[25] Distributions of misorientation axes describing plagioclase subgrain boundaries are plotted on inverse pole figures in Figure 6 . Subgrain boundaries are taken to be those boundaries with misorientation angles between 2 and $15^{\circ}$. All samples except the finest-grained sample (Kn180-19-4) exhibit strong preferred orientations of misorientation axes. Misorientation axes tend to cluster between [100] and [001]. This observation is consistent with subgrain boundaries being built out of (010)[100] and (010)[001] edge dislocations during progressive subgrain-rotation recrystallization [e.g., Lloyd et al., 1997]. Preferred misorientationaxis orientations in rocks with mylonitic fabrics provide further confirmation that intragranular dislocation creep was facilitating recrystallization [Wheeler et al., 2001]. The paucity of subgrain boundaries in sample $\mathrm{Kn} 180-19-4$ is consistent with the interpretation that the sample was deforming dominantly by diffusion creep [Fliervoet et al., 1999; Sundberg and Cooper, 2008]. Interestingly, two samples with relatively weak CPOs (Jas112-32 and Jas11320b) also have a significant number of subgrain boundaries, and the misorientation axes associated with those boundaries are clustered near [100] and [001]. We interpret the lack of a strong CPO in these samples to reflect simultaneous diffusion creep in the numerous finegrained neoblasts and dislocation creep in the few coarse-grained porphyroclasts that are still forming subgrain boundaries as a part of the recrystallization process.

\subsubsection{CPOs: Olivine}

[26] Olivine CPOs are plotted in Figure 7. Sample Kn180-17-14, a harzburgite mylonite, exhibits a well-developed CPO with an M-index of 0.21 . The [100] axes are subparallel to the lineation defined by elongated pyroxene grains and olivine porphyroclasts. The [010] axes are roughly normal to the shear plane, but both [010] and [001] axes form weak, diffuse girdles perpendicular to the lineation. This type of fabric is frequently seen in naturally deformed lithospheric peridotites [e.g., Ismail and Mainprice, 1998; Karato et al., 2008; Warren et al., 2008] and high-strain laboratory experiments [e.g., Bystricky et al., 2000; Hansen et al., 2012]. Nicolas and Christensen [1987] interpreted girdling of [010] and [001] axes to indicate activation of the $\{0 \mathrm{kl}\}[100]$ family of slip systems, which is likely dominated by the (010)[100] and
(001)[100] slip systems [Warren et al., 2008]. However, the presence of [010] and [001] maxima suggests that (010)[100] has accommodated most of the deformation. In other, more highly altered samples, olivine occurs in clusters of equigranular polygonal grains. These olivine grains do not exhibit undulose extinction or subgrain development, but optical inspection with a retardation plate suggests a strong CPO for most samples, implying they are neoblasts formed during dynamic recrystallization in a manner similar to that described for sample Kn180-17-14.

[27] We also analyzed olivine CPOs for two of the peridotite aggregates in sample Jas112-93 (Figure 7). Because this sample consists of peridotite aggregates hosted in a meta-gabbroic matrix, the dominant peridotite foliation is unclear. Both aggregates have strong CPOs, which indicates a large contribution from dislocation motion to the total deformation and is consistent with the dominant mechanism being either dislocation creep [Zhang and Karato, 1995; Zhang et al., 2000] or dislocation-accommodated grain boundary sliding [Hansen et al., 2011, 2012]. The lack of information regarding the shear direction or shear plane prevents interpretation of a dominant slip system from the CPO. Importantly, the dominant axis directions in either aggregate are not parallel, which suggests that the aggregates were rotated with respect to each other. We interpret these observations to indicate that the peridotite was first deformed plastically and subsequently intruded and broken up by a basaltic melt that crystallized as a gabbro.

[28] Distributions of misorientation axes describing olivine subgrain boundaries are plotted on inverse pole figures in Figure 7. All analyzed regions in the peridotites exhibit strong preferred misorientation-axis orientations. Misorientation axes are dominantly distributed between [001] and [010], as would be expected for subgrain boundaries that are built from $\{0 \mathrm{kl}\}[100]$ edge dislocations. The similarity in misorientation-axis distributions between samples Kn180-17-14 and Jas112-93 indicates that dislocations with similar slip systems were contributing to subgrain boundary formation. Notably, misorientation axes measured in Kn180-17-14a tend to be more aligned with [010], which suggests (001)[100] dislocations were dominant in this region. Because Kn180-17$14 \mathrm{a}$ is only $\sim 1 \mathrm{~cm}$ away from $\mathrm{Kn} 180-17-14 \mathrm{~b}$, we suggest the predominance of misorientation axes 
$\left[\begin{array}{lll}1 & 0 & 0\end{array}\right]\left[\begin{array}{lll}0 & 1 & 0\end{array}\right] \quad\left[\begin{array}{lll}0 & 0 & 1\end{array}\right]$

Kn180-17-14a 1786 grains $\max =4.2$ $\mathrm{M}=\mathbf{0 . 2 1}$
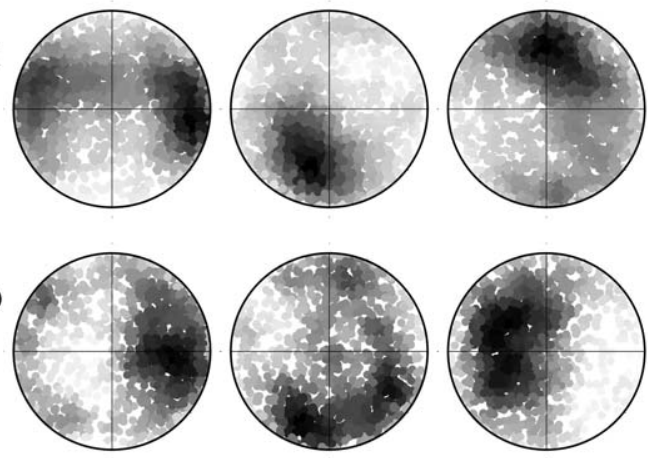
$M=0.13$

Kn180-17-14b 1169 grains $\max =3.1$

Jas112-93a 516 grains $\max =5.3$ $M=0.24$
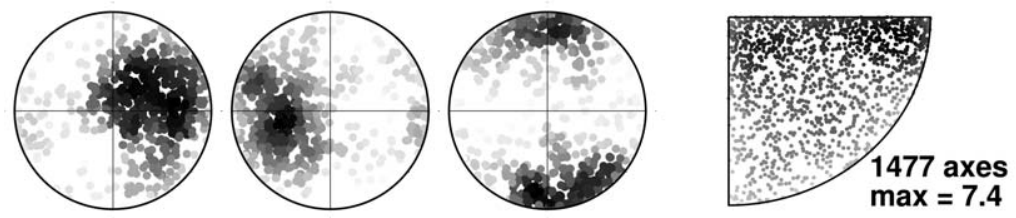
Jas112-93b 701 grains $\max =\mathbf{5 . 0}$ $M=0.15$
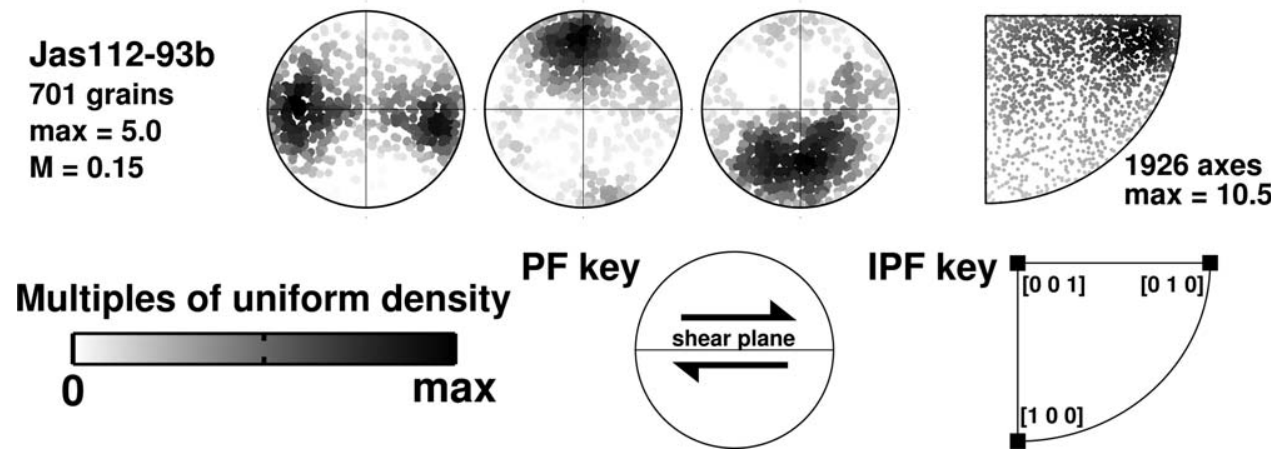

Figure 7. Pole figures (PF) and inverse pole figures (IPF) for olivine in the peridotites. For pole figures, all EBSD data were filtered to one point per grain, and the number of grains is given along with the calculated M-index. All pole figures are lower-hemisphere, equal-area plots. For inverse pole figures, correlated misorientations between $2^{\circ}$ and $15^{\circ}$ are plotted in the crystallographic reference frame. Details of the reference frames are given in the legend.

near [010] reflects the orientation of the host grain or grains from which the measured grains were nucleated.

\subsubsection{Gabbro Thermometry}

[29] Temperatures during mylonitization of gabbroic rocks were calculated from both the amphibole gabbros and from the gabbronorite (Table 2). Hornblende and plagioclase neoblast pairs from samples Jas112-32 and Jas113-20 yield temperatures between $706^{\circ} \mathrm{C}$ and $797^{\circ} \mathrm{C} \pm 40^{\circ}$, in good agreement with temperatures suggested by the inferred slip system in plagioclase. We assume that these temperatures reflect conditions during mylonitization because measurements were made on neoblasts of both hornblende and plagioclase, which likely equilibrated during deformation- related recrystallization. These calculated temperatures are also consistent with the observation that high-temperature microstructures reflect deformation at depths below the BPT and at temperatures below the solidus.

[30] Six orthopyroxene-clinopyroxene pairs were also analyzed from sample Kn180-19-2, a gabbronorite. Calculated temperatures range from $872^{\circ} \mathrm{C} \pm 27^{\circ}$ to $914^{\circ} \mathrm{C} \pm 17^{\circ}$. These pyroxene grains are neoblasts formed during dynamic recrystallization from nearby pyroxene crystals that are several orders of magnitude larger. Therefore, we suggest that these temperatures represent the highest temperatures of deformation determined for the Kane OCC. 
Table 2. Summary of Temperatures Calculated by Geothermometers

\begin{tabular}{|c|c|c|c|c|c|c|c|c|}
\hline \multicolumn{3}{|c|}{$\begin{array}{l}\text { Jas112-32 }{ }^{\mathrm{a}} \\
{[\text { Holland and }} \\
\text { Blundy, 1994] }\end{array}$} & \multicolumn{3}{|c|}{$\begin{array}{c}\text { Jas113-20 }{ }^{\mathrm{a}} \\
{[\text { Holland and }} \\
\text { Blundy, 1994] }\end{array}$} & \multicolumn{3}{|c|}{$\begin{array}{l}\text { Kn180-19-12 } \\
\text { (Ca-QUILF) }\end{array}$} \\
\hline \multicolumn{2}{|c|}{ Analyses } & \multirow{2}{*}{$\frac{\mathrm{T}\left({ }^{\circ} \mathrm{C}\right)}{850}$} & \multicolumn{2}{|c|}{ Analyses } & \multirow{2}{*}{$\frac{\mathrm{T}\left({ }^{\circ} \mathrm{C}\right)}{757}$} & \multicolumn{2}{|c|}{ Analyses } & \multirow{2}{*}{$\frac{\mathrm{T}\left({ }^{\circ} \mathrm{C}\right)}{910}$} \\
\hline P4 & $\mathrm{Hb} 4$ & & P20 & $\mathrm{Hb} 17$ & & CPX8 & OPX9 & \\
\hline P5 & $\mathrm{Hb} 5$ & 863 & P21 & Hb18 & 765 & CPX10 & OPX9 & 891 \\
\hline P6 & $\mathrm{Hb} 6$ & 794 & P24 & $\mathrm{Hb} 21$ & 794 & CPX22 & OPX19 & 872 \\
\hline P7 & $\mathrm{Hb} 7$ & 862 & P25 & $\mathrm{Hb} 22$ & 791 & CPX24 & OPX21 & 901 \\
\hline P8 & $\mathrm{Hb} 8$ & 868 & P28 & $\mathrm{Hb} 25$ & 758 & СРX29 & OPX26 & 905 \\
\hline P9 & $\mathrm{Hb} 9$ & 874 & P29 & $\mathrm{Hb} 26$ & 792 & СРX30 & OPX27 & 914 \\
\hline P10 & $\mathrm{Hb} 10$ & 843 & P30 & $\mathrm{Hb} 27$ & 752 & & & \\
\hline P11 & Hb11 & 853 & P32 & $\mathrm{Hb} 29$ & 753 & & & \\
\hline P12 & $\mathrm{Hb} 12$ & 818 & P33 & $\mathrm{Hb} 30$ & 727 & & & \\
\hline \multirow[t]{7}{*}{ P13 } & $\mathrm{Hb} 13$ & 808 & P34 & $\mathrm{Hb} 31$ & 771 & & & \\
\hline & & & P35 & $\mathrm{Hb} 32$ & 775 & & & \\
\hline & & & P36 & $\mathrm{Hb} 33$ & 770 & & & \\
\hline & & & P37 & $\mathrm{Hb} 34$ & 759 & & & \\
\hline & & & P38 & $\mathrm{Hb} 35$ & 797 & & & \\
\hline & & & P39 & $\mathrm{Hb} 36$ & 789 & & & \\
\hline & & & P41 & $\mathrm{Hb} 38$ & 707 & & & \\
\hline
\end{tabular}

${ }^{\mathrm{a}} \mathrm{P}=$ plaglioclase $; \mathrm{Hb}=$ hornblende.

\section{Discussion}

\subsection{Deep Root of the Kane Oceanic Detachment Fault}

[31] The observations described above prescribe a fault system that rooted sufficiently deep for hightemperature, viscous deformation to be dominant. The package of mylonites near the main detachment surface is concordant with overprinting brittle fabrics, and therefore mylonitic microstructures likely record the highest temperatures at which the detachment was operating. Mylonitic microstructures in peridotites and gabbros are characterized by subgrain development, core and mantle structure, and strong CPOs. These structures are clearly indicative of deformation accommodated by hightemperature processes, particularly dislocation mechanisms and transport of material by diffusion [e.g., Poirier, 1985; Passchier and Trouw, 2005]. The measured recrystallized grain sizes record relatively large differential stresses (Table 1), which suggests that the observed mylonitic textures are more likely related to detachment faulting than to suprasolidus emplacement (for mafic rocks) or asthenospheric flow (for ultramafic rocks). Following the scheme of Rutter [1986] and Kohlstedt et al. [1995], the presence of high-temperature mylonites suggests that the upper part of the footwall of the detachment fault was at some point deforming viscously at depths below the BPT. There is also clear evidence for a downtemperature trend in textures akin to those observed in other investigations of detachment related rocks [Schroeder and John, 2004; Miranda and John, 2010; Picazo et al., 2012]. This observation is consistent with the footwall rocks deforming as they were being transported upward through the BPT into a zone of semibrittle deformation and eventually through the brittle-ductile transition where brittle deformation localized into the narrow fault now exposed as the detachment fault surface.

[32] Further constraint on the depth of faulting can be obtained from the morphology of the breakaway ridge in the vicinity of Abel Dome (Figure 8), from which we can estimate the original depth of fault rocks exposed at East Fault when detachment faulting began. The current dip of the east slope of the breakaway ridge indicates that $26^{\circ}$ of flexural rotation has occurred. Following the method of Smith et al. [2008], the amount of rotation indicated by the dip of the east slope of the breakaway ridge combined with the current dip of the west slope requires that the dip of the detachment fault at initiation was $\sim 48^{\circ}$. Thus, because the East Fault scarp at Cain Dome is $\sim 10 \mathrm{~km}$ east of the breakaway ridge, the rocks exposed on the scarp were at $\sim 7 \mathrm{~km}$ depth when faulting initiated. Error in the fault dip of $\pm 5^{\circ}$ results in $<1 \mathrm{~km}$ variation in the calculated depth.

[33] Recent thermochronometry provides additional constraints on the depth of the detachment faulting. Schoolmeesters [2011] and Schoolmeesters et al. [2011] used both U-Pb and (U-Th)/He chronometers to calculate zircon ages from gabbros in the same sample suite used here. Assuming a fault dip of $48^{\circ}$ (as outlined above), and following the method outlined by Grimes et al. [2011], they demonstrated that footwall rocks passed through the $735^{\circ} \mathrm{C}$ and $190^{\circ} \mathrm{C}$ isotherms at $6.0-8.0$ $\mathrm{km}$ and $1.5-2.5 \mathrm{~km}$ below seafloor, respectively, in good agreement with our prediction of hightemperature deformation at depths of $\sim 7 \mathrm{~km}$.

[34] Several models have been proposed for the deep roots of OCC detachment faults, including the fault rooting into an alteration front [Escartin et al., 2003], into a magma chamber or melt-rich zone [Dick et al., 2000], into the boundary between gabbro intrusions and weakened hydrated peridotite [Ildefonse et al., 2007] or into the BPT [Tucholke et al., 1998, 2001, 2008]. Escartín et al. [2003] proposed that the detachment fault at $15^{\circ} 45^{\prime} \mathrm{N}$ rooted into an alteration front corresponding to temperatures of $300-450^{\circ} \mathrm{C}$. The hightemperature deformation presented in this study clearly requires the fault at the Kane OCC to have 


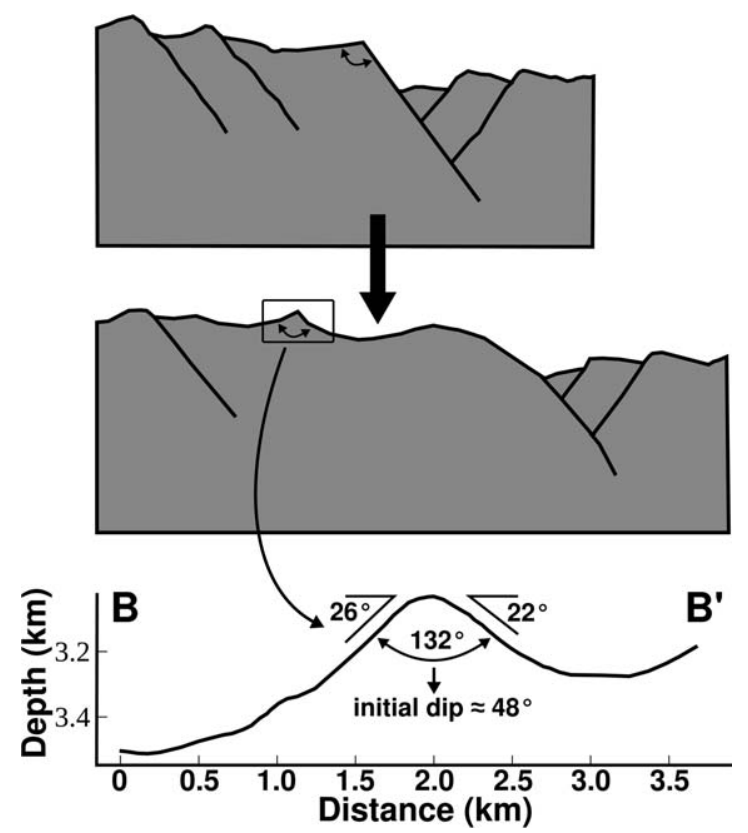

Figure 8. Calculation of initial fault dip from breakaway topography. The upper two plots schematically indicate the manner in which the initial dip angle is preserved at the breakaway after tectonic denudation and flexure of the footwall [modified from Tucholke et al., 2001]. The lower plot depicts a cross section through the breakaway measured near Abel Dome, yielding an initial fault dip of $48^{\circ}$. Location of $\mathrm{B}-\mathrm{B}^{\prime}$ is indicated in Figure 1b.

rooted at a much deeper structural level. Because of the extensive gabbroic intrusions observed in Ocean Drilling Program (ODP) Hole 735B, Dick et al. [2000] proposed that the Atlantis Bank detachment fault rooted into a melt-rich zone where new oceanic crust was continuously accreted in the footwall as it was tectonically denuded. This model allows for the interaction of detachment-related shear zones with melt, as well as high-temperature deformation, both of which are suggested here for the Kane OCC. However, the large proportion of ultramafic rocks composing Cain and Abel Domes implies that magmatism was relatively limited. Therefore, we suggest that any nucleation of shear zones into a melt-rich zone at the Kane OCC was transient and constrained to small areas with respect to the overall mylonitic zone. Ildefonse et al. [2007] argued that oceanic detachment faults can nucleate at the contact between gabbroic intrusions and the surrounding peridotite due to local serpentinization, which is consistent with several OCCs being cored by large gabbro bodies. Similar processes may have been important on the east flank of Cain Dome in which high seismic velocities indicate the presence of a large gabbroic intrusion $[X u$ et al.,
2009]. However, local serpentinization would only contribute to localization at higher structural levels at which low enough temperatures for stable formation of serpentine would be achieved $\left(\mathrm{T}<\sim 550^{\circ} \mathrm{C}\right)$ [e.g., Ulmer and Trommsdorff, 1995]. Additionally, the relative paucity of gabbros collected from Abel Dome and the west flank of Cain Dome along with the observation that some gabbros intrude already mylonitized peridotites demonstrates that deformation can also localize into relatively unaltered ultramafic rocks.

[35] We propose that our observations are consistent with a detachment fault system that roots into or below the BPT (Figure 9). We stress that a detachment fault rooting into the BPT does not imply that material below the BPT translated without deformation. Rather, Figure 9 depicts a distributed zone of mylonitic deformation whose upper boundary roughly corresponds to the BPT. The active mylonitic shear zones also interact with small gabbroic intrusions, some of which may be partially molten. With increasing depth, this zone of mylonitic deformation must transition into distributed asthenospheric mantle flow. Above the BPT some mylonitization may be still active and likely is accommodated by semibrittle processes. The active portion of the system progressively narrows into a zone of intense localized brittle deformation characterized by hydration of mineral phases; relict mylonitic shear zones away from the localized fault see only static alteration.

\subsection{Rheological Profile of an Oceanic Detachment Fault}

[36] To quantify the rheological properties of the Kane detachment fault, we use observed microstructures in combination with laboratory-derived constitutive equations. For the viscously deforming portion of the fault system, rock deformation can be described by a flow law of the form

$$
\dot{\varepsilon}=A \frac{\sigma^{n}}{d^{p}} \exp \left(\frac{-Q}{R T}\right)
$$

where $\dot{\varepsilon}$ is the strain rate, $A$ is a materialdependent constant, $\sigma$ is the differential stress, $n$ is the stress exponent, $d$ is the average grain size, $p$ is the grain size exponent, $Q$ is the activation enthalpy, $R$ is the gas constant, and $T$ is temperature. The term $A$ can be expanded to describe dependencies of the strain rate on a variety of other state variables including the water fugacity, the oxygen 

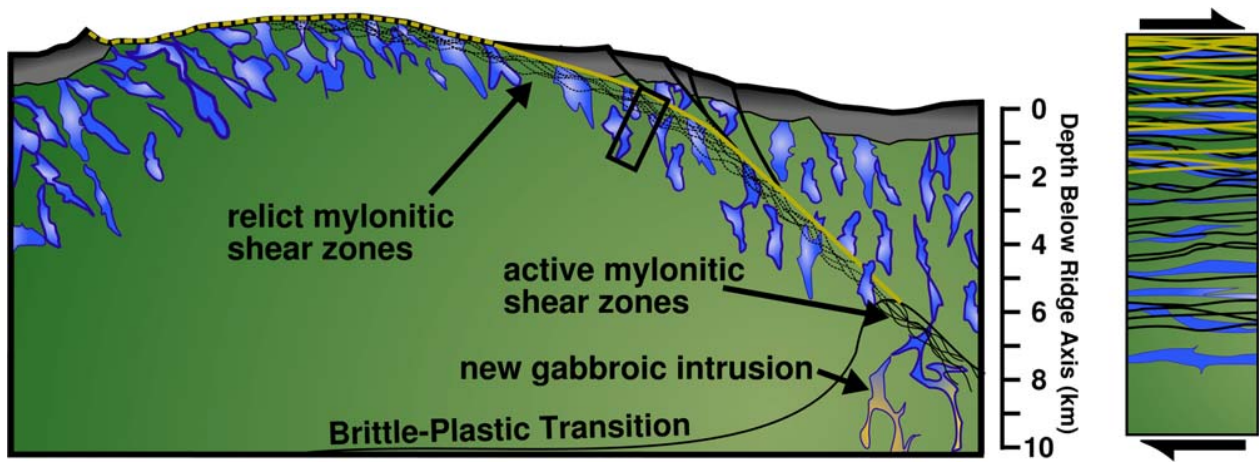

Figure 9. Cartoon describing the tectonic denudation of the Cain and Abel Domes of the Kane OCC. Gabbroic rocks are depicted as shades of blue and peridotite as shades of green, with gray portions representing the volcanic carapace. A zone of distributed, high-temperature, mylonitic shear zones extends below the BPT. Discrete gabbroic intrusions are incorporated into some shear zones. The BPT is warped upward in response to the advection of hot material. Above the BPT, some shear zones continue to be active in a semibrittle mode of deformation while others are abandoned in favor of a localized brittle damage zone (yellow line). Due to limited magmatism, peridotite (and serpentinite) and small gabbroic lenses in the footwall are exposed on the sea floor. The inset schematically depicts the distributions of rock type, mylonitic shear zones (black lines), and brittle shear zones (yellow lines).

fugacity, and the melt fraction [Hirth and Kohlstedt, 2003].

[37] The flow law in equation (1) describes the deformation behavior of a single phase or polyphase material dominated by a single deformation mechanism. In general, multiple deformation mechanisms operate simultaneously. Viscous deformation mechanisms such as dislocation creep, diffusion creep, and dislocation-accommodated grain-boundary sliding are often considered to be operating independently of each other. Thus, a constitutive relationship describing the total strain rate of the material can be written as a summation of the strain rates due to each mechanism,

$$
\dot{\varepsilon}=\sum_{i} \dot{\varepsilon}_{i}=\sum_{i} A_{i} \frac{\sigma^{n_{i}}}{d^{p_{i}}} \exp \left(\frac{-Q_{i}}{R T}\right)
$$

where $i$ denotes the value for the $i$ th deformation mechanism.

[38] Figure 10a presents temperature and differential stress predictions for the samples presented in this study compared to calculated differential stress as a function of temperature using flow-law parameters for wet plagioclase $\left(0.07 \mathrm{wt} \% \mathrm{H}_{2} \mathrm{O}\right)$, dry plagioclase, and dry olivine. To calculate differential stresses at a given temperature, we use parameters for three sets of flow laws and a range of strain rates consistent with those expected in detachment-fault shear zones $\left(10^{-14}\right.$ and $10^{-12.5}$ $\mathrm{s}^{-1}$ ) [John and Cheadle, 2010]. For wet and dry plagioclase, we use the diffusion creep and dislo- cation creep flow-law parameters for $\mathrm{An}_{100}$ plagioclase from Rybacki and Dresen [2000]. For dry olivine, we use the dislocation creep and diffusion creep flow laws from Hirth and Kohlstedt [2003] and the dislocation-accommodated grain-boundary sliding flow law from Hansen et al. [2011]. We modify the pre-exponential constant, $A$, for diffusion creep of olivine according to Hansen et al. [2011]. The evolution of grain size with changing stress conditions can be approximated using empirically derived piezometric relationships for plagioclase [Twiss, 1977] and olivine [van der Wal et al.,1993], which take the form

$$
d=\frac{B}{\sigma^{q}} .
$$

[39] The parameters $B$ and $q$ are material dependent constants. After inserting equation (3) into equation (2), the stress at any given temperature can be solved for numerically.

[40] The resulting curves in Figure 10a are compared to values determined by grain size piezometry and geothermometry of gabbros (see Table 1). The measured values are most consistent with stresses predicted using the dry-plagioclase flow law. Notably, the wet-plagioclase flow law dramatically under-predicts the observed stresses at the assumed strain rates. Strain rates of at least $10^{-9} \mathrm{~s}^{-1}$ are necessary for the wet-plagioclase flow law to predict reasonable stress/temperature profiles. An estimate of realistic strain rates can be obtained following the argument of Mehl and 

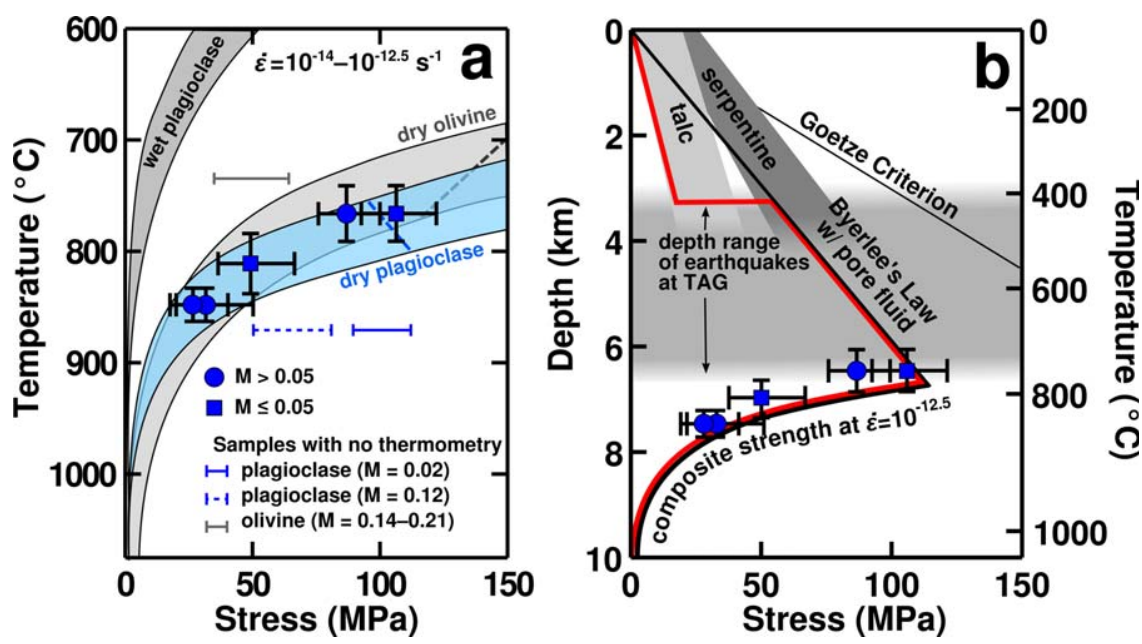

Figure 10. Rheological analysis of the Kane detachment fault. (a) Stress-temperature profiles calculated using laboratory-derived flow laws for plagioclase and olivine. Profiles are illustrated as shaded regions encompassing the stresses predicted for strain rates ranging from $10^{-14}$ to $10^{-12.5} \mathrm{~s}^{-1}$. For dry flow laws, the transition from dislocation creep or dislocation-accommodated grain-boundary sliding to diffusion creep is depicted with a blue dashed line for plagioclase and a grey dashed line for olivine. Stress and temperature calculated from mylonitic samples are presented for comparison. (b) Stress-depth profile including frictional strength at shallow depths. The red line denotes the predicted stress profile assuming fault strength is controlled by talc in the shallowest portions, frictional sliding with a hydrostatic pore fluid in the intermediate portions, and composite viscosity including mafic and ultramafic rocks below the BPT.

Hirth [2008]. Approximately, 20\% of the sampled rocks exhibit significant crystal-plastic deformation fabrics in the upper $450 \mathrm{~m}$ of the profile constructed in Figure 2, which yields a total thickness of viscous shear zones of $\sim 90 \mathrm{~m}$. The fault slip rate has been estimated from $\mathrm{U} / \mathrm{Pb}$ dating of zircon to be $\sim 16.5 \mathrm{~mm} / \mathrm{yr}$ [Cheadle et al., 2008]. Combining fault slip rate and total shear zone thickness yields a maximum shear strain rate of $\sim 6 \times 10^{-12} \mathrm{~s}^{-1}$, which, when converted to an equivalent axial strain rate [Paterson and Olgaard, 2000], is $\sim 3 \times 10^{-12} \mathrm{~s}^{-1}$. Because this estimate is within an order of magnitude of that predicted by dry-plagioclase flow laws using the measured stresses, we suggest that the rheological behavior of the gabbroic rocks in the Kane detachment system are best described by a dry flow law. The difference between our calculated stresses and those predicted from grain size piezometry could potentially be explained by the incorporation of a small amount (i.e., $<0.07 \mathrm{wt} \%$ ) of water into plagioclase [Rybacki and Dresen, 2000] or by geometric softening associated with CPO development [e.g., Hansen et al., 2012]. We note that our estimate of $\sim 90 \mathrm{~m}$ for the total thickness of shear zones would have to be reduced by over 2 orders of magnitude to result in strain rates similar to those necessary for the wet-plagioclase flow law from Rybacki and Dresen [2000] to predict reasonable stresses.
[41] Stresses predicted for olivine-rich rocks are also illustrated in Figure 10a. Although we do not have temperature data to allow comparison between measured stresses and predicted stresses, we note that dry olivine is similar in strength to dry plagioclase at these conditions. The predicted stress profiles for olivine suggest that peridotite mylonites formed at $\sim 800^{\circ} \mathrm{C}$, consistent with observations of shear zones in orogenic peridotites [Linckens et al., 2011a, 2011b].

[42] In further support of the above analysis, data from fault rocks are plotted in Figure 10a with symbols that correspond to the strength of the crystallographic fabric. Samples deformed at the highest stresses, with one exception (Jas113-20a), tend to have the weakest fabrics $(M<0.05)$. The highest measured stresses correlate well with the boundary between deformation dominated by dislocation processes (dislocation creep or dislocation-accommodated grain-boundary sliding) and that dominated by diffusion creep. The weakening of crystallographic fabrics with increased stress (i.e., reduced grain size) is commonly attributed to the increased contribution of diffusion creep to the total strain rate [e.g., Jaroslow et al., 1996; Bestmann and Prior, 2003; Linckens et al., 2011a]. Although we do not have temperature data for olivine-rich rocks, the 
measured stresses are within the dislocationaccommodated grain-boundary sliding regime for a wide range of temperatures, and olivine CPOs correspondingly have relatively high $\mathrm{M}$ indices $(M=0.14-0.24)$.

[43] Plagioclase and olivine flow laws are used to construct the profile of fault strength with increasing depth illustrated in Figure 10b. To describe the deformation behavior of a shear zone intersecting both mafic and ultramafic rocks, we assume the strain rate is spatially constant and the stress varies between plagioclase-rich rocks and olivine-rich rocks, which yields

$$
\sigma_{\text {composite }}=\left(\frac{f_{\text {plag }}}{\sigma_{\text {plag }}}+\frac{f_{\text {ol }}}{\sigma_{o l}}\right)^{-1}
$$

where $f_{\text {plag }}$ and $f_{o l}$ are the volume fractions of plagioclase-rich rocks and olivine-rich rocks, respectively. The above statement is equivalent to the Voigt bound for the bulk properties of multiphase rocks [e.g., Handy, 1994; Ji et al., 2001, 2004]. We use $f_{\text {plag }}=0.4$ and $f_{o l}=0.6$ according to the proportions of deformed rocks collected from dive Jas112 (Figure 2). Alternatively, using a constant-stress assumption (Reuss bound) produces qualitatively similar results because olivine and plagioclase have similar strengths under the relevant conditions. Figure $10 \mathrm{~b}$ demonstrates that the predicted composite stress for a strain rate of $10^{-12.5} \mathrm{~s}^{-1}$ is in good agreement with the data obtained from the gabbro mylonites.

[44] To convert the temperature profile used in Figure 10a to a depth profile, we calculate a temperature-depth relationship following Faul and Jackson [2005]. Values for the potential temperature, heat capacity, coefficient of thermal expansion, thermal diffusivity, and age of the lithosphere are taken to be $1573 \mathrm{~K}, 1350 \mathrm{Jkg}^{-1}$ $\mathrm{K}^{-1}, 2.9 \times 10^{-5} \mathrm{~K}^{-1}, 10^{-12} \mathrm{~m}^{2} \mathrm{~s}^{-1}$, and $1 \mathrm{Myr}$, respectively. Gabbro mylonites with calculated temperatures plot between 6 and $8 \mathrm{~km}$ below the seafloor. The resulting temperature-depth relationship agrees with the constraints provided by zircon $\mathrm{U} / \mathrm{Pb}$ and $(\mathrm{U}-\mathrm{Th}) / \mathrm{He}$ geo- and thermochronology from gabbros collected from Cain and Abel Domes that suggest temperatures of $735^{\circ} \mathrm{C}$ at $5-8$ $\mathrm{km}$ below the sea floor [Schoolmeesters, 2011].

[45] The maximum stresses observed place important bounds on the rheological behavior of the shallow portion of the fault system. The maximum stress measured among deformed rocks is on the order of $100 \mathrm{MPa}$, which is a minimum estimate of the stress at the BPT. This value is at least a factor of 2 less than the stress at the intersection of the viscous strength curve and the Goetze Criterion, which is often used as a proxy for the BPT [Kohlstedt et al., 1995]. Interestingly, the maximum measured stress is in good agreement with the intersection of the viscous strength curve and Byerlee's Law when the pore fluid pressure is assumed to be hydrostatic. This assumption appears reasonable since the earliest deformation to overprint mylonitic fabrics is accompanied by alteration of the primary minerals to hydrous phases. Notably, pore fluid pressures greater than hydrostatic would result in a brittle strength less than the measured maximum stress of viscous deformation and are therefore unlikely. Several studies have provided evidence for interaction of seawater with the brittle and semibrittle portions of oceanic detachment faults, which includes petrographic and isotopic observations [MacLeod et al., 2002; Escartín et al., 2003; Boschi et al., 2006, 2008; McCaig et al., 2010; Picazo et al., 2012]. Additionally, the maximum depth of microearthquakes recorded at the Trans-Atlantic Geotraverse (TAG) detachment system [deMartin et al., 2007] correlates well with the depth of maximum stress recorded in mylonitic rocks from the Kane detachment system. Thus, we conclude that the transition from plastic to semibrittle and brittle deformation occurs at 6-7 km depth, at $\sim 750^{\circ} \mathrm{C}$, and $\sim 100 \mathrm{MPa}$ differential stress.

[46] The strength of the shallow portion of the fault may also be significantly affected by alteration products including talc and serpentine. The frictional strengths of serpentine and talc are depicted in Figure 10b. The strength of serpentine is similar to that predicted by Byerlee's Law modified by a hydrostatic pore pressure [Escartín et al., 1997, 2001]. However, the temperature range of serpentine stability is constrained to be below $\sim 550^{\circ} \mathrm{C}$ at $10 \mathrm{~km}$ depth [e.g., Ulmer and Trommsdorff., 1995], and is therefore unlikely to be controlling portions of the fault just above the BPT. The strength of talc is significantly lower than that predicted by Byerlee's Law [Escartín et al., 2008], consistent with the model of Ildefonse et al. [2007] that suggests retrograde reaction products at gabbro-peridotite contacts (e.g., talc-tremolitechlorite assemblages) will be significantly weaker at shallow depths than either gabbro or peridotite host rocks. However, if talc were controlling the strength of the entire brittle portion of the fault, then the intersection of the brittle and viscous 

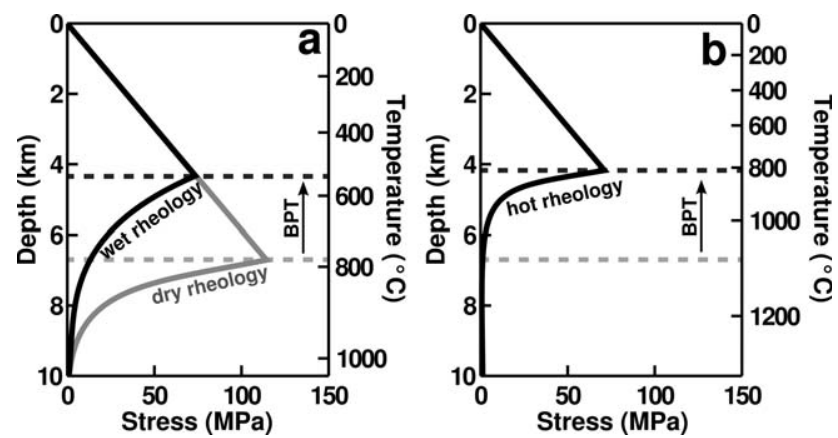

Figure 11. Response of the BPT to changes in the viscous strength curves for the deepest portion of the detachment fault system. (a) Compositional variation. The strength of the viscous portion of the fault is significantly reduced if the constituent rocks are sufficiently hydrated, which decreases the depth of the brittle plastic transition by $\sim 2 \mathrm{~km}$. This effect increases the time over which rocks are deforming viscously allowing for larger strains to be reached and, therefore, development of thicker zones of mylonites. Crystallization of "wet" gabbros at Atlantis Bank might be responsible for the significant thickness of mylonitic rocks observed there [John and Cheadle, 2010]. (b) A similar effect can be induced by increasing the temperature such that isotherms are compressed upward. All calculations are for a strain rate of $10^{-12.5} \mathrm{~s}^{-1}$.

strength curves would be at much lower stresses than measured by piezometry. Because of the prevalence of talc-tremolite-chlorite schists collected from oceanic detachment faults [MacLeod et al., 2002; Escartín et al., 2003; Schroeder and John, 2004; Boschi et al., 2006], we argue that talc controls the strength of the shallowest portion of the fault. We note that a transition from stronger rock-types to talc-rich rocks might be indicated by the lack of seismicity in the upper $\sim 3 \mathrm{~km}$ of the TAG detachment system [deMartin et al., 2007]. Such a change in the dominant mineralogy would likely correspond to a change in the coefficient of internal friction, which may be responsible for the abrupt change in the apparent dip of the detachment fault at TAG [deMartin et al., 2007].

[47] The strength profile depicted in Figure $10 \mathrm{~b}$ highlights two primary factors that control the strength of the detachment system. First, the viscosity of the mylonitic portion of the system is the primary factor determining the strength of the fault. Decreasing the viscous strength of the constituent rocks will shift the viscous portion of the strength profile to shallower depths (Figure 11a), reducing both the maximum stress and the integrated strength of the system. An overall decrease in viscous strength can be facilitated by hydrolitic weakening [e.g., Kohlstedt, 2006], increased temperatures resulting in compression of isotherms toward the sea floor, or the interaction of the detachment system with a partially molten region (Figure 11b). Second, weakening of the shallowest portion of the system through the production of weak alteration products also dramatically lowers the integrated strength.

\subsection{Comparison to Other OCCs}

[48] Investigations of fault rocks at other OCCs have yielded a variety of results regarding the rheological nature of oceanic detachment faults. Examinations of fault rocks collected in Integrated Ocean Drilling Program (IODP) Hole 1309D at Atlantis Massif [Hirose and Hayman, 2008; McCaig et al., 2010], as surface samples from the OCC at $15^{\circ} 45^{\prime} \mathrm{N}$ [MacLeod et al., 2002; Escartín et al., 2003], and in ODP Leg 209 drill cores from Hole $1275 \mathrm{~B}$ at $15^{\circ} 45^{\prime} \mathrm{N}$ [Kelemen et al., 2004] have found a relative paucity of strong crystalplastic fabrics. In contrast, substantial mylonitization has been observed along the south wall of Atlantis Massif in a region that is dominantly peridotite [Schroeder and John, 2004; Karson et al., 2006] and in ODP Hole 735B at Atlantis Bank. Karson et al. [2006] mapped a $100 \mathrm{~m}$ thick zone of deformation-induced foliation near the detachment surface at Atlantis Massif by sampling a mass-wasting scarp that exposed the interior of the main dome. Based on profiles reconstructed from the same scarp by Schroeder and John [2004] (their Table 3), the proportion of rocks with crystal-plastic fabric intensity $\geq 2$ suggests a total thickness of viscous shear zones of $\sim 40 \mathrm{~m}$. Mylonitization is pervasive at Atlantis Bank and estimates for the total thickness of viscous shear zones range from $150 \mathrm{~m}$ [Mehl and Hirth, 2008] to $400 \mathrm{~m}$ [Miranda and John, 2010], depending on the criterion used to define mylonitic deformation. The observations and interpretations presented here regarding the depth extent and style of deformation at the Kane OCC are clearly more in line with those at the south wall of Atlantis Massif and 
Atlantis Bank than they are with the rocks in IODP Hole 1309D and ODP Leg 209 boreholes.

[49] We suggest that the differences in the abundance of crystal-plastic deformation fabrics recorded at the above mentioned OCCs can be explained through a simple rheological argument. First, it is worth noting that the semiquantitative scale ubiquitously used to describe crystal-plastic deformation at OCCs is effectively a measure of strain because the observation is based on the volume fraction of recrystallized grains, which is strongly strain dependent [e.g., Drury, 2005]. Often the total thickness of high-temperature deformation is estimated by the number of rocks above a certain threshold in fabric strength [Mehl and Hirth, 2008; Miranda and John, 2010] (we have chosen to use fabric intensities $\geq 2$ ). This approach overlooks the possibility that many other rocks are deforming viscously but have only experienced small strains. For instance, although core recovered from IODP Hole U1309D records relatively few rocks hosting a crystal-plastic fabric strength $>2$ [Blackman et al., 2006; Hirose and Hayman, 2008], there is a substantial thickness of rock that exhibits weak crystal-plastic fabrics parallel to the main cataclastic structures. Fault systems that extend farther below the BPT will allow larger viscous strains to be accumulated. Thus, detachment faults with little or no mylonitization may have resulted from a relatively deep BPT while those with significant mylonitization may have resulted from a relatively shallow BPT.

[50] Several factors can affect the depth of the BPT (Figure 11). In short, the BPT is shallower for weaker rocks. A reduction in rock strength can be due to composition (e.g., water or melt content) or compression of isotherms to shallower depths. We posit that detachment faults associated with limited viscous deformation, such as at the $\mathrm{OCC}$ at $15^{\circ} 45^{\circ} \mathrm{N}$, are relatively strong because they are cold and/or dry. In contrast, we suggest that oceanic detachment faults exhibiting pervasive high- $T$ deformation, such as at the Kane OCC and Atlantis Massif, are relatively hot and possibly weakened by a small amount of dissolved water and/or their interaction with partially molten rocks. Further, we suggest that oceanic detachment faults such as at Atlantis Bank, which exhibits the most abundant mylonitization, are weakened further by the incorporation of water-related crystal defects into plagioclase as gabbros crystallized from a hydrous melt [John and Cheadle, 2010]. This last suggestion is supported by piezometry and ther- mometry that yields relatively low stresses and high strain rates in amphibole-bearing gabbros from Atlantis Bank [Miranda, 2006].

\section{Conclusions}

[51] In an effort to characterize the rheological behavior of oceanic detachment faults, we examine a suite of rocks collected from the Kane oceanic core complex at $23^{\circ} \mathrm{N}$ on the Mid-Atlantic Ridge. We focus on rock samples from Cain and Abel Domes and the scarp associated with East Fault, which exposes the interior of Cain Dome. The analyzed section is dominantly peridotite with lesser gabbroic rocks.

[52] Reconstruction of a profile down the East Fault scarp reveals a $\sim 450 \mathrm{~m}$ zone of hightemperature mylonitization and a $200 \mathrm{~m}$ zone of brittle deformation in the upper part of this zone that make up the exposed portion of the detachment fault system. The high-temperature mylonitic portion is composed of a series of centimeter-thick to meter-thick anastomosing shear zones with interspersed lenses of relatively undeformed rock. The morphology of the breakaway ridge indicates that the fault system extended to depths $>7 \mathrm{~km}$, which agrees with recent estimates from zircon geochronology. Geothermometry of dynamically recrystallized neoblasts yields temperatures of deformation greater than $700^{\circ} \mathrm{C}$. Petrography of mylonitic fabrics, grain size piezometry, analysis of crystallographic fabrics, and comparison to laboratory-derived flow laws confirm that hightemperature deformation occurred by a combination of dislocation creep, dislocationaccommodated grain-boundary sliding, and diffusion creep with grain size sensitive processes dominating at the smallest grain sizes. The stresses measured by grain size piezometry are best explained by dry flow laws of plagioclase and olivine and strain rates near $10^{-14}-10^{-12.5} \mathrm{~s}^{-1}$. Faster strain rates $\left(3 \times 10^{-12} \mathrm{~s}^{-1}\right)$ are indicated by the spatial distribution of shear zones and estimated slip rates, which can be explained by weakening of the mylonites by either a small addition of water or geometric softening associated with CPO development.

[53] Our microstructural and rheological analysis demonstrates that the Kane detachment fault system extends into or below the BPT. The highest differential stresses estimated from analysis of mylonites provide a minimum estimate of the stress at the BPT $(\sim 100 \mathrm{MPa})$. Notably, this 
estimated stress at the BPT is in good agreement with that predicted by the intersection of the dry viscous flow laws and Byerlee's Law with a hydrostatic pore fluid. We suggest that most oceanic detachment faults extend below the BPT and that the variation in the abundance of mylonites among OCCs can be explained by variations in the depth of the BPT, which controls the amount of viscous strain that can be accumulated. Thus, differences in water content and/or the thermal structure of the oceanic lithosphere can control the degree of mylonitization through their effect on the depth of the BPT.

\section{Acknowledgments}

[54] Knorr Cruise 180-2 data and sample acquisition was supported by NSF grant 0118445 . We gratefully acknowledge the hard work and contributions of the shipboard scientific party and the Jason II ROV and ABE AUV groups and give special thanks to Joshua Schwartz for detailed analysis of hand samples. The quality of the manuscript was much improved by comments from Nicholas Hayman, Othmar Müntener, and an anonymous reviewer. This work benefitted from discussions with Greg Hirth, Peter Kelemen, David Prior, and Holger Stünitz.

\section{References}

Agar, S., and G. Lloyd (1997), Deformation of Fe-Ti oxides in gabbroic shear zones from the MARK area, Proc. Ocean Drill. Program Sci. Results, 153, 123-141.

Anderson, D. J., D. H. Lindsley, and P. M. Davidson (1993), QUILF: A Pascal program to assess equilibria among FeMg-Mn-Ti oxides, pyroxenes, olivine and quartz, Comput. Geosci., 19(9), 1333-1350, doi:10.1016/0098-3004(93)900 33-2.

Bestmann, M., and D. Prior (2003), Intragranular dynamic recrystallization in naturally deformed calcite marble: Diffusion accommodated grain boundary sliding as a result of subgrain rotation recrystallization, J. Struct. Geol., 25(10), 1597-1613, doi:10.1016/S0191-8141(03)00006-3.

Blackman, D., B. Ildefonse, B. John, Y. Ohara, D. Miller, and C. MacLeod (2006), Oceanic core complex formation, Atlantis Massif, Proc. Ocean Drill. Program Sci. Results, 304/305, http://dx.doi.org/10.2204/iodp.proc.304305.2006.

Blackman, D. K., J. R. Cann, B. Janssen, and D. K. Smith (1998), Origin of extensional core complexes: Evidence from the Mid-Atlantic Ridge at Atlantis Fracture Zone, $J$. Geophys. Res., 103(B9), 21,315-21,333, doi:10.1029/ 98JB01756.

Blackman, D. K., et al. (2011), Drilling constraints on lithospheric accretion and evolution at Atlantis Massif, MidAtlantic Ridge 30 N, J. Geophys. Res., 116, B07103, doi: 10.1029/2010JB007931.

Boschi, C., G. L. Früh-Green, A. Delacour, J. A. Karson, and D. S. Kelley (2006), Mass transfer and fluid flow during detachment faulting and development of an oceanic core complex, Atlantis Massif (MAR 30 N), Geochem. Geophys. Geosyst., 7, Q01004, doi:10.1029/2005GC001074.
Boschi, C., A. Dini, G. Früh-Green, and D. Kelley (2008), Isotopic and element exchange during serpentinization and metasomatism at the Atlantis massif (MAR $\left.30^{\circ} \mathrm{N}\right)$ : Insights from $\mathrm{B}$ and $\mathrm{Sr}$ isotope data, Geochim. Cosmochim. Acta, 72(7), 1801-1823, doi:10.1016/j.gca.2008.01.013.

Brey, G. P., and T. Köhler (1990), Geothermobarometry in four-phase lherzolites II, New thermobarometers, and practical assessment of existing thermobarometers, J. Petrol., 31(6), 1353-1378, doi:10.1093/petrology/31.6.1353.

Buck, W. R., L. L. Lavier, and A. N. B. Poliakov (2005), Modes of faulting at mid-ocean ridges, Nature, 434(7034), 719-723, doi:10.1038/nature03358.

Bystricky, M., K. Kunze, L. Burlini, and J. P. Burg (2000), High shear strain of olivine aggregates; rheological and seismic consequences, Science, 290(5496), 1564-1567, doi: $10.1126 /$ science.290.5496.1564.

Cann, J. R., D. K. Blackman, D. Smith, E. McAllister, B. Janssen, S. Mello, E. Avgerinos, A. R. Pascoe, and J. Escartin (1997), Corrugated slip surfaces formed at ridge-transform intersections on the Mid-Atlantic Ridge, Nature, 385(6614), 329-332, doi:10.1038/385329a0.

Cannat, M. (1991), Plastic deformation at an oceanic spreading ridge: A microstructural study of the Site 735 gabbros (Southwest Indian Ridge), Proc. Ocean Drill. Program Sci. Results, 118, 399-408.

Cannat, M., D. Sauter, V. Mendel, E. Ruellan, K. Okino, J. Escartin, V. Combier, and M. Baala (2006), Modes of seafloor generation at a melt-poor ultra-slow spreading ridge, Geology, 34, 605-608, doi:10.1130/G22486.1.

Cheadle, M. J., B. E. John, M. Lusk, and J. Wooden (2008), Asymmetric spreading and the construction of Oceanic crust at the Kane Oceanic Core Complex, Eos Trans. AGU, 89(53), Fall Meet. Suppl., Abstract T41D-04.

Dale, J., T. Holland, and R. Powell (2000), Hornblende-garnetplagioclase thermobarometry: A natural assemblage calibration of the thermodynamics of hornblende, Contrib. Mineral. Petrol., 140(3), 353-362, doi:10.1007/s004100000187.

deMartin, B., R. Sohn, J. Canales, and S. Humphris (2007), Kinematics and geometry of active detachment faulting beneath the Trans-Atlantic geotraverse (tag) hydrothermal field on the Mid-Atlantic Ridge, Geology, 35(8), 711-714, doi: 10.1130/G23718A.1.

Dick, H. J. B., P. S. Meyer, S. Bloomer, S. Kirby, D. Stakes, and C. Mawer (1991), Lithostratigraphic evolution of an insitu section of oceanic crust, Proc. Ocean Drill. Program Sci. Results, 118, 439-538.

Dick, H. J. B., J. H. Natland, and D. J. Miller (1999), Proceedings of the Ocean Drilling Program, Initial Reports, vol. 1976, Ocean Drill. Program, College Station, Tex.

Dick, H. J. B., et al. (2000), A long in situ section of the lower ocean crust: Results of ODP Leg 176 drilling at the Southwest Indian Ridge, Earth Planet. Sci. Lett., 179(1), 31-51, doi:10.1016/S0012-821X(00)00102-3.

Dick, H. J. B., M. A. Tivey, and B. E. Tucholke (2008), Plutonic foundation of a slow- spreading ridge segment: Oceanic core complex at Kane Megamullion, $23^{\circ} 30^{\prime} \mathrm{N}$, $45^{\circ} 20^{\prime} \mathrm{W}$, Geochem. Geophys. Geosyst., 9, Q05014, doi: 10.1029/2007GC001645.

Drury, M. (2005), Dynamic recrystallization and strain softening of olivine aggregates in the laboratory and the lithosphere, Geol. Soc. Spec. Publ., 243(1), 143-158, doi:10.1144/GSL.SP.2005.243.01.11.

Drury, M. R., and J. L. Urai (1990), Deformation-related recrystallization processes, Tectonophysics, 172(3-4), 235-253, doi:10.1016/0040-1951(90)90033-5. 
Escartín, J., G. Hirth, and B. Evans (1997), Effects of serpentinization on the lithospheric strength and the style of normal faulting at slow-spreading ridges, Earth Planet. Sci. Lett., 151(3), 181-189.

Escartín, J., G. Hirth, and B. Evans (2001), Strength of slightly serpentinized peridotites: Implications for the tectonics of oceanic lithosphere, Geology, 29(11), 1023-1026, doi: 10.1016/S0012-821X(97)81847-X.

Escartín, J., C. Mevel, C. J. MacLeod, and A. M. McCaig (2003), Constraints on deformation conditions and the origin of oceanic detachments: The Mid-Atlantic Ridge core complex at $15^{\circ} 45^{\prime} \mathrm{N}$, Geochem. Geophys. Geosyst., 4(8), 1067, doi: $10.1029 / 2002 \mathrm{GC} 000472$.

Escartín, J., D. K. Smith, J. Cann, H. Schouten, C. H. Langmuir, and S. Escrig (2008), Central role of detachment faults in accretion of slow-spreading oceanic lithosphere, Nature, 455(7214), 790-794, doi:10.1038/ nature 07333 .

Fabries, J. (1979), Spinel-olivine geothermometry in peridotites from ultramafic complexes, Contrib. Mineral. Petrol., 69(4), 329-336, doi:10.1007/BF00372258.

Faul, U. H., and I. Jackson (2005), The seismological signature of temperature and grain size variations in the upper mantle, Earth Planet. Sci. Lett., 234(1-2), 119-134, doi:10.1016/ j.eps1.2005.02.008.

Fliervoet, T. F., M. R. Drury, and P. N. Chopra (1999), Crystallographic preferred orientations and misorientations in some olivine rocks deformed by diffusion or dislocation creep, Tectonophysics, 303(1-4), 1-27, doi:10.1016/S00401951(98)00250-9.

Grimes, C., M. Cheadle, B. John, P. Reiners, and J. Wooden (2011), Cooling rates and the depth of detachment faulting at oceanic core complexes: Evidence from zircon $\mathrm{Pb} / \mathrm{U}$ and (U-Th)/He ages, Geochem. Geophys. Geosyst., 12, Q0AG01, doi:10.1029/2010GC003391.

Handy, M. R. (1994), Flow laws for rocks containing two nonlinear viscous phases: A phenomenological approach, $J$. Struct. Geol., 16(3), 287-301, doi:10.1016/0191-8141(94)9 0035-3.

Hansen, L. N., M. E. Zimmerman, and D. L. Kohlstedt (2011), Grain-boundary sliding in San Carlos olivine: Flow-law parameters and crystallographic-preferred orientation, J. Geophys. Res., 116, B08201, doi:10.1029/2011JB008 220.

Hansen, L. N., M. E. Zimmerman, and D. L. Kohlstedt (2012), The influence of microstructure on deformation of olivine in the grain-boundary sliding regime, J. Geophys. Res., 117, B09201, doi: 10.1029/2012JB009305.

Harigane, Y., K. Michibayashi, and Y. Ohara (2008), Shearing within lower crust during progressive retrogression: Structural analysis of gabbroic rocks from the Godzilla Mullion, an oceanic core complex in the Parece Vela backarc basin, Philippine Sea, Tectonophysics, 457, 183-196, doi:10.1016/ j.tecto.2008.06.009.

Hirose, T., and N. Hayman (2008), Structure, permeability, and strength of a fault zone in the footwall of an oceanic core complex, the central dome of the Atlantis Massif, MidAtlantic Ridge, $30^{\circ} \mathrm{N}$, J. Struct. Geol., 30(8), 1060-1071, doi:10.1016/j.jsg.2008.04.009.

Hirth, G., and D. Kohlstedt (2003), Rheology of the mantle wedge, in Inside the Subduction Factory, Geophys. Monogr. Ser., vol. 138, pp. 83-105, AGU, Washington, D. C.

Hirth, G., and J. Tullis (1992), Dislocation creep regimes in quartz aggregates, J. Struct. Geol., 14(2), 145-159, doi: 10.1016/0191-8141(92)90053-Y.
Holland, T., and J. Blundy (1994), Non-ideal interactions in calcic amphiboles and their bearing on amphiboleplagioclase thermometry, Contrib. Mineral. Petrol., 116(4), 433-447, doi:10.1007/BF00310910.

Ildefonse, B., D. K. Blackman, B. E. John, Y. Ohara, D. J. Miller, C. J. MacLeod, and the Integrated Ocean Drilling Program Expeditions 304/305 Science Party (2007), Oceanic core complexes and crustal accretion at slow spreading ridges, Geology, 35, 623-626, doi:10.1130/G23531A.1.

Ismail, W. B., and D. Mainprice (1998), An olivine fabric database: an overview of upper mantle fabrics and seismic anisotropy, Tectonophysics, 296(1-2), 145-157, doi: 10.1016/S0040-1951(98)00141-3.

Jaroslow, G., G. Hirth, and H. Dick (1996), Abyssal peridotite mylonites: Implications for grain-size sensitive flow and strain localization in the oceanic lithosphere, Tectonophysics, 256(1-4), 17-37, doi:10.1016/0040-1951(95)00163-8.

Ji, S., and D. Mainprice (1990), Recrystallization and fabric development in plagioclase, J. Geol., 98(1), 65-79.

Ji, S., Z. Wang, and R. Wirth (2001), Bulk flow strength of forsterite-enstatite composites as a function of forsterite content, Tectonophysics, 341(1-4), 69-93, doi:10.1016/S00401951(01)00191-3.

Ji, S., Z. Jiang, E. Rybacki, R. Wirth, D. Prior, and B. Xia (2004), Strain softening and microstructural evolution of anorthite aggregates and quartz-anorthite layered composites deformed in torsion, Earth Planet. Sci. Lett., 222(2), 377-390, doi:10.1016/j.epsl.2004.03.021.

John, B. E., and M. J. Cheadle (2010), Deformation and alteration associated with oceanic and continental detachment fault systems: Are they similar?, in Diversity of Hydrothermal Systems on Slow Spreading Ocean Ridges, Geophys. Monogr. Ser., vol. 188, edited by P. A. Rona, et al., pp. 175-205, AGU, Washington, D. C., doi:10.1029/ 2008GM000772.

Karato, S., H. Jung, I. Katayama, and P. Skemer (2008), Geodynamic significance of seismic anisotropy of the upper mantle: New insights from laboratory studies, Annu. Rev. Earth Planet. Sci., 36, 59-95, doi:10.1146/annurev.earth.36. 031207.124120

Karson, J., G. L. Früh-Green, D. S. Kelley, E. A. Williams, D. R. Yoerger, and M. Jakuba (2006), Detachment shear zone of the Atlantis Massif core complex, Mid-Atlantic Ridge, $30^{\circ} \mathrm{N}$, Geochem. Geophys. Geosyst., 7, Q06016, doi: 10.1029/2005GC001109.

Kelemen, P. B., et al. (2004), Proceedings of the Ocean Drilling Program, Initial Reports, vol. 209, Ocean Drill. Program, College Station, Tex. (Available at http://wwwodp.tamu.edu/publications/209_IR/209ir.htm).

Kohlstedt, D. (2006), The role of water in high-temperature rock deformation, Rev. Mineral. Geochem., 62(1), 377-396.

Kohlstedt, D. L., B. Evans, and S. J. Mackwell (1995), Strength of the lithosphere: Constraints imposed by laboratory experiments, J. Geophys. Res., 100(17), 587-617, doi: 10.1029/95JB01460.

Lavier, L. L., W. R. Buck, and A. N. B. Poliakov (1999), Selfconsistent rolling-hinge model for the evolution of largeoffset low-angle normal faults, Geology, 27(12), 1127-1130, doi:10.1130/0091-7613(1999)027<1127:SCR $\mathrm{HMF}>2.3 . \mathrm{CO} ; 2$.

Linckens, J., M. Herwegh, O. Müntener, and I. Mercolli (2011a), Evolution of a polymineralic mantle shear zone and the role of second phases in the localization of deformation, J. Geophys. Res., 116, B06210, doi:10.1029/201 0JB008119. 
Linckens, J., M. Herwegh, and O. Müntener (2011b), Linking temperature estimates and microstructures in deformed polymineralic mantle rocks, Geochem. Geophys. Geosyst., 12, Q08004, doi:10.1029/2011GC003536.

Lindsley, D. H., and B. R. Frost (1992), Equilibria among Fe-Ti oxides, pyroxenes, olivine, and quartz; part I, theory, Am. Mineral., 77(9-10), 987-1003.

Lloyd, G. E., A. B. Farmer, and D. Mainprice (1997), Misorientation analysis and the formation and orientation of subgrain and grain boundaries, Tectonophysics, 279(1-4), 55-78, doi:10.1016/S0040-1951(97)00115-7.

MacLeod, C. J., et al. (2002), Direct geological evidence for oceanic detachment faulting: The Mid-Atlantic Ridge, $15^{\circ} 45^{\prime} \mathrm{N}$, Geology, 30(10), 879-882, doi:10.1130/00917613(2002)030<0879:DGEFOD $>2.0 . C O ; 2$.

MacLeod, C. J., R. C. Searle, B. J. Murton, J. F. Casey, C. Mallows, S. C. Unsworth, K. L. Achenbach, and M. Harris (2009), Life cycle of oceanic core complexes, Earth Planet. Sci. Lett., 287(3), 333-344, doi:10.1016/j.epsl.2009.08.016.

Maia, M., and P. Gente (1998), Three-dimensional gravity and bathymetry analysis of the Mid-Atlantic Ridge between $20^{\circ} \mathrm{N}$ and $24^{\circ} \mathrm{N}$ : Flow geometry and temporal evolution of the segmentation, J. Geophys. Res., 103, 951-974, doi:10.1029/97JB01635.

Manning, C. E., P. E. Weston, and K. I. Mahon (1996), Rapid high-temperature metamorphism of East Pacific Rise gabbros from Hess Deep, Earth Planet. Sci. Lett., 144(1-2), 123-132, doi:10.1016/0012-821X(96)00153-7.

McCaig, A., A. Delacour, A. Fallick, T. Castelain, and G. Fruh-Green (2010), Detachment fault control on hydrothermal circulation systems: Interpreting the subsurface beneath the TAG hydrothermal field using the isotopic and geological evolution of oceanic core complexes in the Atlantic, in Diversity of Hydrothermal Systems on Slow Spreading Ocean Ridges, Geophys. Monogr. Ser., vol. 188, pp. 207-240, AGU, Washington, D. C.

Mehl, L., and G. Hirth (2008), Plagioclase preferred orientation in layered mylonites: Evaluation of flow laws for the lower crust, J. Geophys. Res., 113, B05202, doi:10.1029/ 2007JB005075.

Miranda, E. (2006), Structural Development of the Atlantis Bank Oceanic Detachment Fault System, Southwest Indian Ridge, Ph.D. thesis, Dep. of Geol. and Geophys., Univ. of Wyo., Laramie.

Miranda, E., and B. John (2010), Strain localization along the Atlantis Bank oceanic detachment fault system, Southwest Indian Ridge, Geochem. Geophys. Geosyst., 11, Q04002, doi:10.1029/2009GC002646.

Mutter, J. C., and J. A. Karson (1992), Structural processes at slow-spreading ridges, Science, 257(5070), 627-634, doi:10.1126/science.257.5070.627.

Nicolas, A., and N. I. Christensen (1987), Formation of anisotropy in upper mantle peridotites: A review, in Composition, Structure and Dynamics of the Lithosphere-Asthenosphere System, Geophys. Monogr. Ser., vol. 16, edited by K. Fuchs and C. Froidevaux, pp. 111-123, AGU, Washington, D. C.

Ohara, Y., K. Fujioka, T. Ishii, and H. Yurimoto (2003), Peridotites and gabbros from the Parece Vela backarc basin: Unique tectonic window in an extinct backarc spreading ridge, Geochem. Geophys. Geosyst., 4(7), 8611, doi: 10.1029/2002GC000469.

Olive, J. A., M. D. Behn, and B. E. Tucholke (2010), The structure of oceanic core complexes controlled by the depth distribution of magma emplacement, Nat. Geosci., 3(7), 491-495, doi:10.1038/ngeo888.

Olsen, T. S., and D. Kohlstedt (1984), Analysis of dislocations in some naturally deformed plagioclase feldspars, Phys. Chem. Miner., 11(4), 153-160.

Passchier, C., and R. Trouw (2005), Microtectonics, Springer, New York.

Paterson, M., and D. Olgaard (2000), Rock deformation tests to large shear strains in torsion, J. Struct. Geol., 22(9), 1341-1358, doi:10.1016/S0191-8141(00)00042-0.

Paulick, H., W. Bach, M. Godard, J. De Hoog, G. Suhr, and J. Harvey (2006), Geochemistry of abyssal peridotites (Mid-Atlantic Ridge, $15^{\circ} 20^{\prime} \mathrm{N}$, ODP Leg 209): Implications for fluid/rock interaction in slow spreading environments, Chem. Geol., 234(3), 179-210, doi:10.1016/j.chemgeo. 2006.04.011.

Picazo, S., M. Cannat, A. Delacour, J. Escartin, S. Roumejon, and S. Silantiev (2012), Deformation associated with the tectonic denudation of mantle-derived ultramafic rocks at the Mid-Atlantic Ridge $13^{\circ}-15^{\circ} \mathrm{N}$ : The role of magmatic injections and hydrothermal alteration, Geochem. Geophys. Geosyst., 13, Q04G09, doi:10.1029/2012GC 004121.

Poirier, J.-P. (1985), Creep of Crystals: High-Temperature Deformation Processes in Metals, Ceramics and Minerals, Cambridge Univ. Press, New York.

Rutter, E. H. (1986), On the nomenclature of mode of failure transitions in rocks, Tectonophysics, 122(3-4), 381-387, doi:10.1016/0040-1951(86)90153-8.

Rybacki, E., and G. Dresen (2000), Dislocation and diffusion creep of synthetic anorthite aggregates, J. Geophys. Res., 105(B11), 26,017-26,036, doi:10.1029/2000JB900223.

Sack, R., and M. Ghiorso (1991), Chromian spinels as petrogenetic indicators; thermodynamics and petrological applications, Am. Mineral., 76(5-6), 827-847.

Schoolmeesters, N. (2011), Cooling histories and depth of oceanic detachment faulting at the MidAtlantic Ridge: Constraints from thermochronometry, MS thesis, Dep. of Geol. and Geophys., Univ. of Wyo., Laramie.

Schoolmeesters, N., M. Cheadle, B. E. John, and P.W. Reiners (2011), Determining cooling histories and depth of detachment faulting of oceanic core complexes using $\mathrm{U}-\mathrm{Pb}$ and (U-Th)/He thermochronometry, Geol. Soc. Am. Abstr. Programs, 43(5), 654.

Schroeder, T., and B. John (2004), Strain localization on an oceanic detachment fault system, Atlantis Massif, $30^{\circ} \mathrm{N}$, Mid-Atlantic Ridge, Geochem. Geophys. Geosyst., 5(11), Q11007, doi:10.1029/2004GC000728.

Schroeder, T., M. Cheadle, H. Dick, U. Faul, J. Casey, and P. Kelemen (2007), Nonvolcanic seafloor spreading and corner-flow rotation accommodated by extensional faulting at $15^{\circ} \mathrm{N}$ on the Mid-Atlantic Ridge: A structural synthesis of ODP Leg 209, Geochem. Geophys. Geosyst., 8, Q06015, doi:10.1029/2006GC001567.

Searle, R. C., and J. Escartin (2004), The rheology and morphology of oceanic lithosphere and mid-ocean ridges, in Mid-Ocean Ridges: Hydrothermal Interactions Between the Lithosphere and Oceans, Geophys. Monogr. Ser., vol. 148, edited by C. German, J. Lin, and L. Parson, pp. 63-94, AGU, Washington, D. C.

Skemer, P., I. Katayama, Z. Jiang, and S. Karato (2005), The misorientation index: Development of a new method for calculating the strength of lattice-preferred orientation, Tectonophysics, 411(1-4), 157-167, doi:10.1016/j.tecto.2005.08. 023. 
Smith, D. K., J. R. Cann, and J. Escartin (2006), Widespread active detachment faulting and core complex formation near $13^{\circ} \mathrm{N}$ on the Mid-Atlantic Ridge, Nature, 442(7101), 440-443, doi:10.1038/nature04950.

Smith, Deborah K., J. Escartín, H. Schouten, and J. R. Cann (2008), Fault rotation and core complex formation: Significant processes in seafloor formation at slow-spreading midocean ridges (Mid-Atlantic Ridge, 13-15 N), Geochem. Geophys, Geosys., 9(3), Q03003, doi:10.1029/ 2007GC001699.

Sundberg, M., and R. F. Cooper (2008), Crystallographic preferred orientation produced by diffusional creep of harzburgite: The effects of chemical interactions amongst phases during plastic flow, J. Geophys. Res., 113, B12208, doi:10.1029/2008JB005618.

Stünitz, H., J. Fitz Gerald, and J. Tullis (2003), Dislocation generation, slip systems, and dynamic recrystallization in experimentally deformed plagioclase single crystals, Tectonophysics, 372(3), 215-233, doi:10.1016/S0040-1951 (03)00241-5.

Tivey, M. A., B. E. Tucholke, and H. J. B. Dick (2004), Kane Megamullion 2004, Cruise Rep. KN180-2, 54 pp., Woods Hole Oceanogr. Inst., Woods Hole, Mass.

Tucholke, B. E., and J. Lin (1994), A geological model for the structure of ridge segments in slow spreading ocean crust, J. Geophys. Res., 99(B6), 11,937-11,958.

Tucholke, B. E., J. Lin, and M. C. Kleinrock (1996), Mullions, megamullions, and metamorphic core complexes on the Mid-Atlantic Ridge, Eos Trans. AGU, 77(46), Fall Meet. Suppl., F724.

Tucholke, B. E., J. Lin, and M. C. Kleinrock (1998), Megamullions and mullion structure defining oceanic metamorphic core complexes on the Mid-Atlantic Ridge, J. Geophys. Res., 103(B5), 9857-9866, doi:10.1029/98JB00167.

Tucholke, B. E., K. Fujioka, T. Ishihara, G. Hirth, and M. Kinoshita (2001), Submersible study of an oceanic megamullion in the central North Atlantic, J. Geophys. Res., 106(B8), 16,145-16,162, doi:10.1029/2001JB000373.

Tucholke, B. E., M. D. Behn, W. R. Buck, and J. Lin (2008), Role of melt supply in oceanic detachment faulting and formation of megamullions, Geology, 36(6), 455-458.
Twiss, R. J. (1977), Theory and applicability of a recrystallized grain size paleopiezometer, Pure Appl. Geophys., 115(1), 227-244, doi:10.1007/BF01637105.

Ulmer, P., and V. Trommsdorff (1995), Serpentine stability to mantle depths and subduction-related magmatism, Science, 268(5212), 858-858, doi:10.1126/science.268.5212. 858 .

Underwood, E. (1970), Quantitative Stereology, pp. 80-93, Addison-Wesley, Reading, Mass.

van der Wal, D., P. Chopra, M. Drury, and J. Fitzgerald (1993), Relationships between dynamically recrystallized grain size and deformation conditions in experimentally deformed olivine rocks, Geophys. Res. Lett., 20(14), 1479-1482, doi:10.1029/93GL01382.

Warren, J., G. Hirth, and P. Kelemen (2008), Evolution of olivine lattice preferred orientation during simple shear in the mantle, Earth Planet. Sci. Lett., 272(3-4), 501-512, doi:10.1016/j.eps1.2008.03.063.

Wheeler, J., D. Prior, Z. Jiang, R. Spiess, and P. Trimby (2001), The petrological significance of misorientations between grains, Contrib. Mineral. Petrol., 141(1), 109-124, doi:10.1007/s004100000225.

Witt-Eickschen, G., and H. Seck (1991), Solubility of Ca and Al in orthopyroxene from spinel peridotite: An improved version of an empirical geothermometer, Contrib. Mineral. Petrol., 106(4), 431-439, doi:10.1007/BF00321986.

Xie, Y., H.-R. Wenk, and S. Matthies (2003), Plagioclase preferred orientation by TOF neutron diffraction and SEMEBSD, Tectonophysics, 370(1-4), 269-286, doi:10.1016/ S0040-1951(03)00191-4.

Xu, M., J. P. Canales, B. E. Tucholke, and D. L. DuBois (2009), Heterogeneous seismic velocity structure of the upper lithosphere at Kane oceanic core complex, MidAtlantic Ridge, Geochem. Geophys. Geosyst., 10, Q10001, doi:10.1029/2009GC002586.

Zhang, S., and S. Karato (1995), Lattice preferred orientation of olivine aggregates deformed in simple shear, Nature, 375(6534), 774-777, doi:10.1038/375774aa0.

Zhang, S., S. Karato, J. Fitzgerald, U. H. Faul, and Y. Zhou (2000), Simple shear de-formation of olivine aggregates, Tectonophysics, 316(1-2), 133-152, doi:10.1016/S00401951(99)00229-2. 